Report No. BMI-1326

UC-25 Metallurgy and Ceramics (TID -4500, 14th Ed.)

Contract No. W-7405-eng-92

\title{
HIGH-TEMPERATURE MECHANICAL PROPERTIES OF TANTALUM
}

by

David C. Drennen

M. Eugene Langston

Charles J. Slunder

Joseph G. Dunleavy

March 2, 1959

\section{BATTELLE MEMORIAL INSTITUTE 505 King Avenue \\ Columbus 1, Ohio}




\section{DISCLAIMER}

This report was prepared as an account of work sponsored by an agency of the United States Government. Neither the United States Government nor any agency Thereof, nor any of their employees, makes any warranty, express or implied, or assumes any legal liability or responsibility for the accuracy, completeness, or usefulness of any information, apparatus, product, or process disclosed, or represents that its use would not infringe privately owned rights. Reference herein to any specific commercial product, process, or service by trade name, trademark, manufacturer, or otherwise does not necessarily constitute or imply its endorsement, recommendation, or favoring by the United States Government or any agency thereof. The views and opinions of authors expressed herein do not necessarily state or reflect those of the United States Government or any agency thereof. 


\section{DISCLAIMER}

Portions of this document may be illegible in electronic image products. Images are produced from the best available original document. 
TABLE OF CONTENTS

Page

ABSTRACT . . . . . . . 1

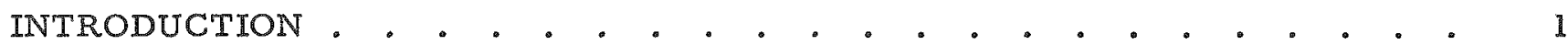

EXPERIMENT AL WORK • . . . . . . . . . . . . . . . . . . . 2

Materials . . . . . . . . . . . . . . . . . . . . . 2

Experimental Equipment . . . . . . . . . . . . . . . . 2

Inert-Atmosphere Creep Furnaces . . . . . . . . . . . . 2

Vacuum-Induction Heating System •. . . . . . . . . . . 7

Creep-Testing Procedure . . . . . . . . . . . . . . . . . 7

Creep and Stress-Rupture Test Results . . . . . . . . . . . . . 9

Annealed Sintered Tantalum . . . . . . . . . . . . . 10

Thermally Degassed Coarse-Grained Sintered Tantalum . . . . 11

Thermally Degassed Fine-Grained Sintered Tantalum . . . . . 17

Annealed Arc-Cast Tantalum . . . . . . . . . . . . . 19

Sodium-Exposed Annealed Sintered Tantalum . . . . . . . . 25

As-Rolled and Welded Arc-Cast Tantalum . . . . . . . . . 25

DISCUSSION

Creep-Test Results 。 . . . . . . . . . . . . . . . . . . 28

Effect of Oxygen and Nitrogen on the Hardness of Tantalum $\quad . \quad \cdot \quad \cdot \quad \cdot \quad \cdot 28$

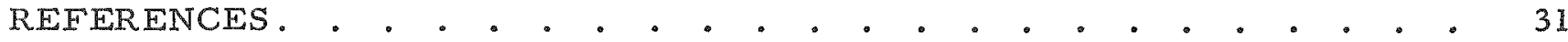




\title{
HIGH-TEMPERATURE MECHANICAL PROPERTIES OF TANTALUM
}

David C. Drennen, M. Eugene Langston, Charles J. Slunder, and Joseph G. Dunleavy

\begin{abstract}
Creep and creep-rupture tests were performed at $1200 \mathrm{~F}$ in helium on arc-cast and on sintered rolled tantalum sheet to investigate the effect of structure and gaseous contamination on the creep resistance of tantalum. A vacuum-induction furnace was developed for annealing and for degassing the as-received cold-worled material. The tests were conducted with inert-atmosphere resistance creep furnaces designed to prevent excessive interstitial-element pickup.
\end{abstract}

The effect of hydrogen, nitrogen, and oxygen on the high-temperature strength of tantalum was not clearly discernible. Degassing of annealed sintered tontalum in flow ing sodium produced in a lower oxygen contamination, but had no significant effect on creep resistance.

The method of manufacture, the grain size, and the treatments performed on the material, on the other hand, produced a substanitial effect on creep resistance. Annealed arc-cast tantalum possessed somewhat higher creep resistance at $1200 \mathrm{~F}$ than did annealed sintered tantalum. The highest creep resistance was found in a fine-grained sintered material which had been degassed 20 to $60 \mathrm{~min}$ at 4500 to $4650 \mathrm{~F}$, cold rolled to an 80 per cent reduction, and then recrystallized 10 to $15 \mathrm{~min}$ at about $2800 \mathrm{~F}$ prior to creep testing. The lowest creep resistance aras noted for an extremely coarse-grained thermally degassed material.

\section{INTRODUCTION}

As part of the evaluation of tartalum as a construction material for LAMPRE, a program was undertaken at Battelle Memorial Institute to investigate the hightemperature mechanical properties of tantalum, and to get some information on the effect of interstitial contaminants on these properties.

Tantalum absorbs hydrogen, nitrogen, and oxygen readily at elevated temperatures. However, it was found at LASL that exposure of commercial tantalum to the fuel in LAMPRE resulted in the removal of oxygen and nitrogen from the metal. Thus, the material is left chemically degassed in reference to these impurities. As a result of this finding, emphasis was placed on testing only material of low gas content. The initial phase of the program was concerned with the development of equipment and procedures for inert-atmosphere creep testing with minimum contamination.

Other objectives of this program were to survey sources of supply of tantalum and to gain information on the quality and purity of commercially available metal, as well as to determine the strength of tantalum weldments. 


\section{EXPERIMENTAL WORK}

Materials

The first substantial quantity of tantalum sheet available to the program was fabricated from sintered powder at the Fansteel Metallurgical Corporation. For this reason, the majority of the tests in this investigation were conducted with this Fansteel sintered tantalum. Later, as different grades of tantalum became available from other sources, additional tests were conducted to supplement the data. These included testing of arc-cast tantalum received from Fansteel and sintered tantalum received from the Kawecki Chemical Company. A lot of high-purity electron-beam-melted tantalum was received from Temescal Metallurgical Corporation too late to be used in the program.

Table 1 presents analytical, grain-size, and hardness data for the various types of tantalum that were received. Not all of these materials were used in the mechanicalproperty testing program. The chemical analyses show that with the passage of time, suppliers became more successful in providing high-purity tantalum. For example, the first Fansteel material used in the testing program had an average oxygen content of about 233 ppm, whereas the Kawecki material, which was used later, had an oxygen content of only $68 \mathrm{ppm}$. The Murex and the Universal-Cyclops tantalum were comparable with the Kawecki material; however, it was preferred to use the Kawecki tantalum because of its lower carbon content.

Figures 1, 2, 3, and 4 show the microstructures of the Fansteel as-rolled sintered tantalum, Fansteel as-rolled arc-cast tantalum, Kawecki sintered tantalum, and Temescal electron-beam-melted tantalum, respectively. Since the materials are in different conditions, no direct comparison of them can be made. The large number of black spots shown in the specimen in Figure 3 have been identified as voids inherent in the material. In Figure 4, it is interesting to note the subgrain boundaries outlined by an unidentified second phase.

\section{Experimental Equipment}

\section{Inert-Atmosphere Creep Furnaces}

In order to avoid excessive interstitial-element pickup by the tantalum during creep testing, it was necessary to design special inert-atmosphere resistance furnaces and to establish suitable testing techniques. The furnace design is shown in Figure 5.

The main features to note are the Inconel muffle for containing the specimen, and the provision for maintaining a small positive pressure of helium within the muffle. The Inconel tube is fitted with brass bellows on each end, and is heated by an external Chromel winding.

Zirconium liners ( 10 mils thick) were placed inside the Inconel tube during the latter part of the program for the purpose of gettering decomposition products of the Inconel, impurities in the helium, and decomposition products from air and water absorbed on the wall of the furnace during down periods. 
TABLE 1. ANALYTICAL, GRAIN-SIZE, AND HARDNESS DATA FOR VARIOUS TYPES OF AS-RECEIVED TANTALUM

\begin{tabular}{|c|c|c|c|c|c|c|c|c|c|}
\hline & Date & & & \multicolumn{4}{|c|}{ Chemical Analysis, ppm } & \multirow{2}{*}{$\begin{array}{c}\text { Average } \\
\text { Grain } \\
\text { Diameter. } \\
\text { mm } \\
\end{array}$} & \multirow{2}{*}{$\begin{array}{c}\text { Hardness, } \\
\text { VHN }\end{array}$} \\
\hline Source & Received & Type & Condition & Oxygen & Nitrogen & Hydrogen & Carbon & & \\
\hline $\begin{array}{l}\text { Fansteel Metallurgical } \\
\text { Corporation }\end{array}$ & $\begin{array}{l}\text { October, } \\
1956\end{array}$ & Sintered & As rolled & $208-259$ & 160 & 0.3 & 20 & Fibrous & 313 \\
\hline $\begin{array}{l}\text { Fansteel Metallurgical } \\
\text { Corporation }\end{array}$ & $\begin{array}{l}\text { May, } \\
1957\end{array}$ & Arc cast & As rolled & $219-260$ & $150-250$ & 1.0 & 10 & Fibrous & $285-374$ \\
\hline $\begin{array}{l}\text { Kawecki Chemical } \\
\text { Company }\end{array}$ & $\begin{array}{l}\text { January, } \\
1958\end{array}$ & Sintered & As sintered & 68 & 40 & 0.2 & 40 & 0.100 & 84 \\
\hline Murex Ltd. & $\begin{array}{l}\text { January, } \\
1958\end{array}$ & Unknown & As rolled & 39 & 60 & 0.6 & 140 & Fibrous & 153 \\
\hline $\begin{array}{l}\text { Universal-Cyclops } \\
\text { Steel Corporation }\end{array}$ & $\begin{array}{c}\text { January, } \\
1958\end{array}$ & Arc cast & As rolled & 47 & 60 & 0.2 & 90 & Fibrous & $58^{(a)}$ \\
\hline $\begin{array}{l}\text { Temescal } \\
\text { Metallurgical } \\
\text { Corporation }\end{array}$ & $\begin{array}{l}\text { April, } \\
1958\end{array}$ & $\begin{array}{l}\text { Electron- } \\
\text { beam } \\
\text { melted }\end{array}$ & As cast & $7-16$ & $10-40$ & $0.5-1.4$ & $20-40$ & 2.2 & $83 \cdots 92$ \\
\hline
\end{tabular}

(a) Rockwell B hardness of material in as-cast condition. 


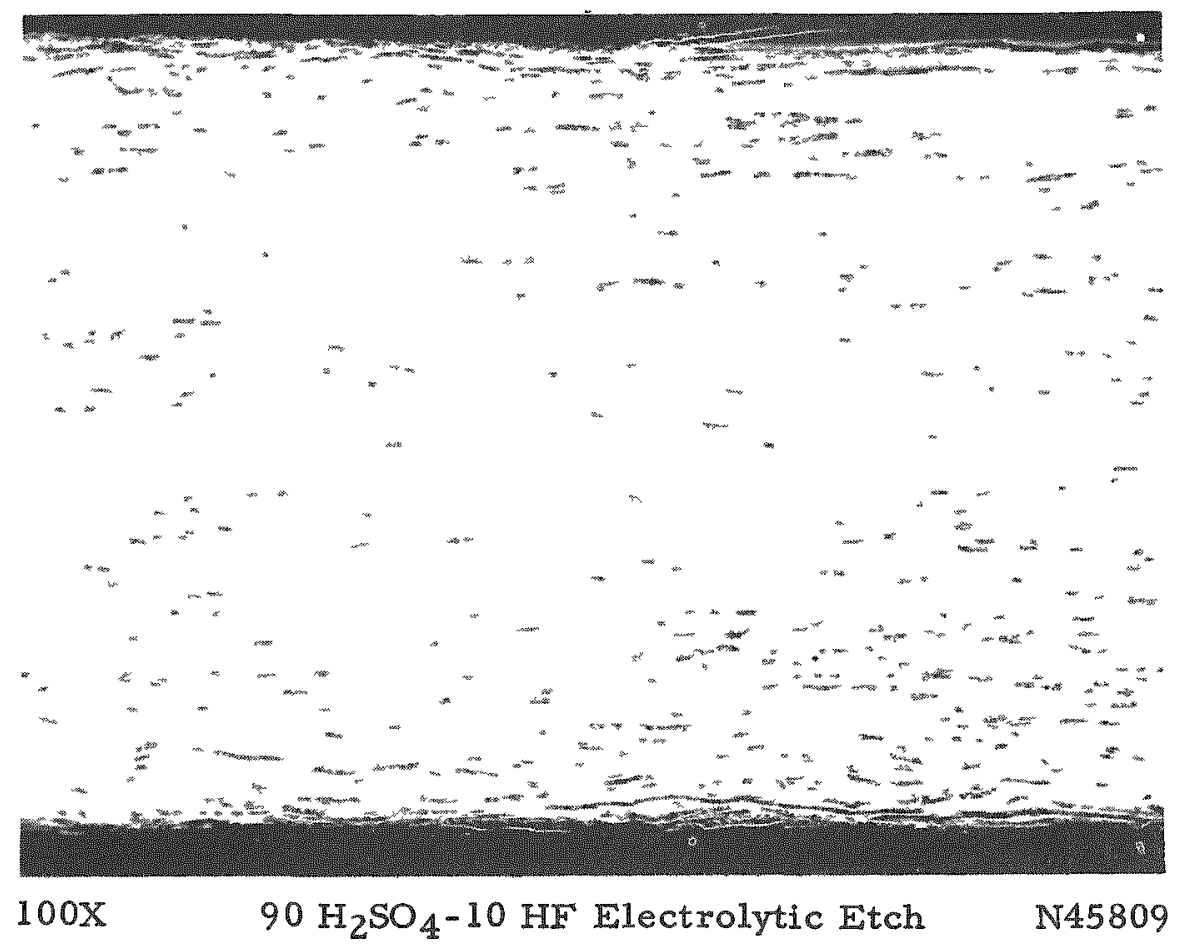

FIGURE 1. PHOTOMICROGRAPH OF CROSS SECTION OF AS-ROLLED 30-MIL FANSTEEL SINTERED TANTALUM

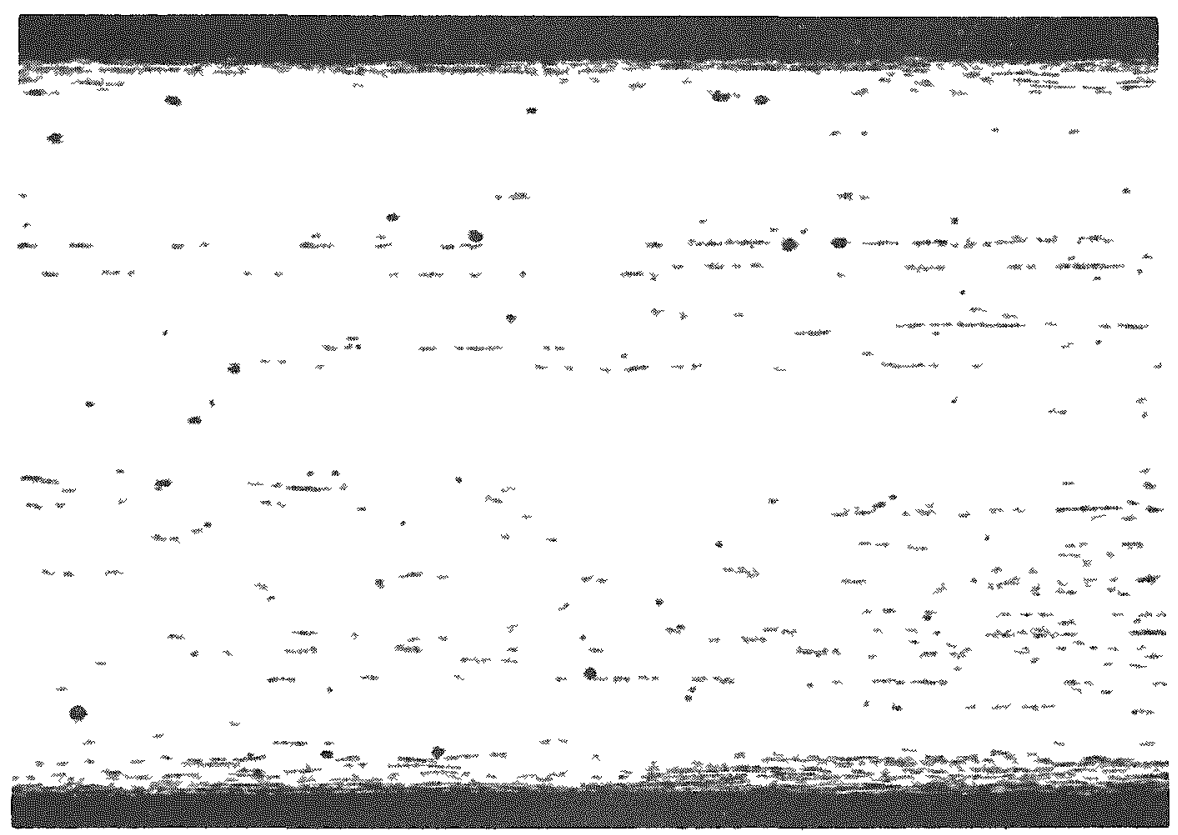

$100 x$

FIGURE 2. PHOTOMICROGRAPH OF CROSS SECTION OF AS-ROLLED 30-MIL FANSTEEL ARC-CAST TANTALUM 


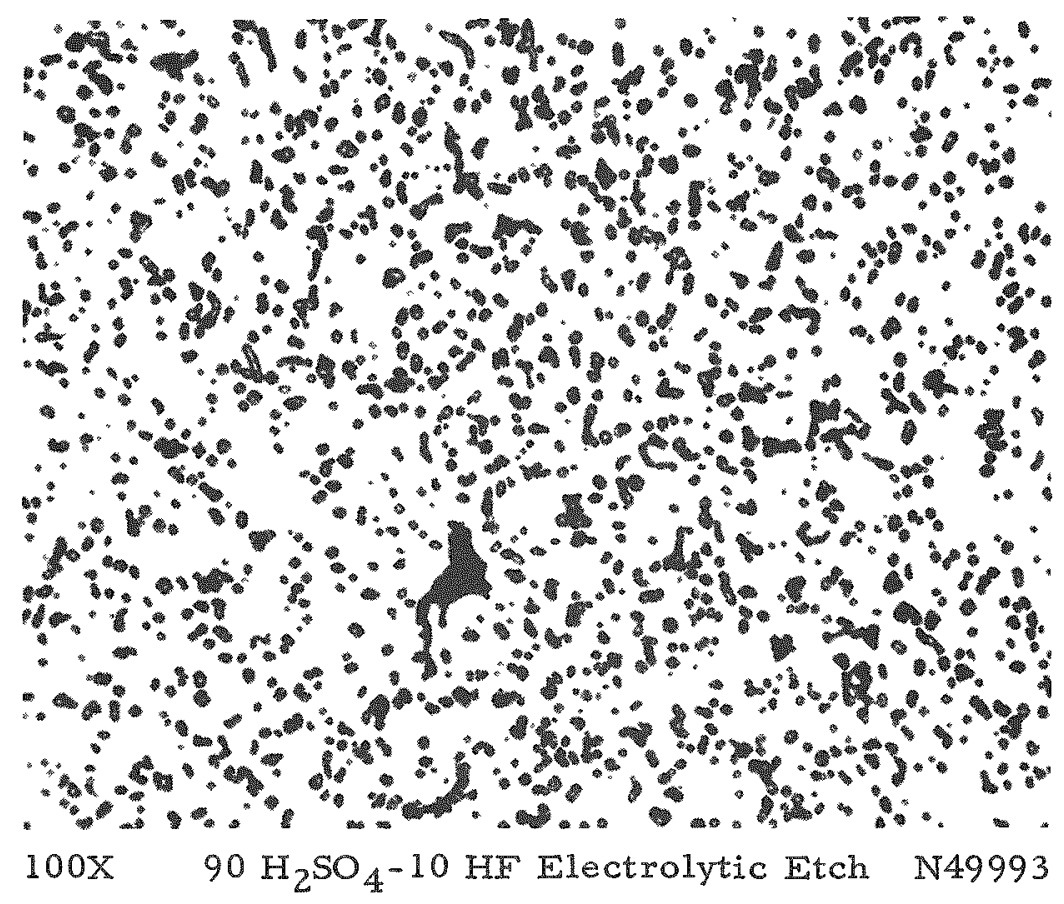

FIGURE 3. AS-SINTERED MICROSTRUCTURE OF KAWECKI SINTERED TANTALUM

$100 \mathrm{X} 90 \mathrm{H}_{2} \mathrm{SO}_{4}-10 \mathrm{HF}$ Electrolytic Etch $\mathrm{N54010}$

FIGURE 4. AS-CAST MICROSTRUCTURE OF TEMESCAL ELECTRONBEAM-MELTED TANTALUM 


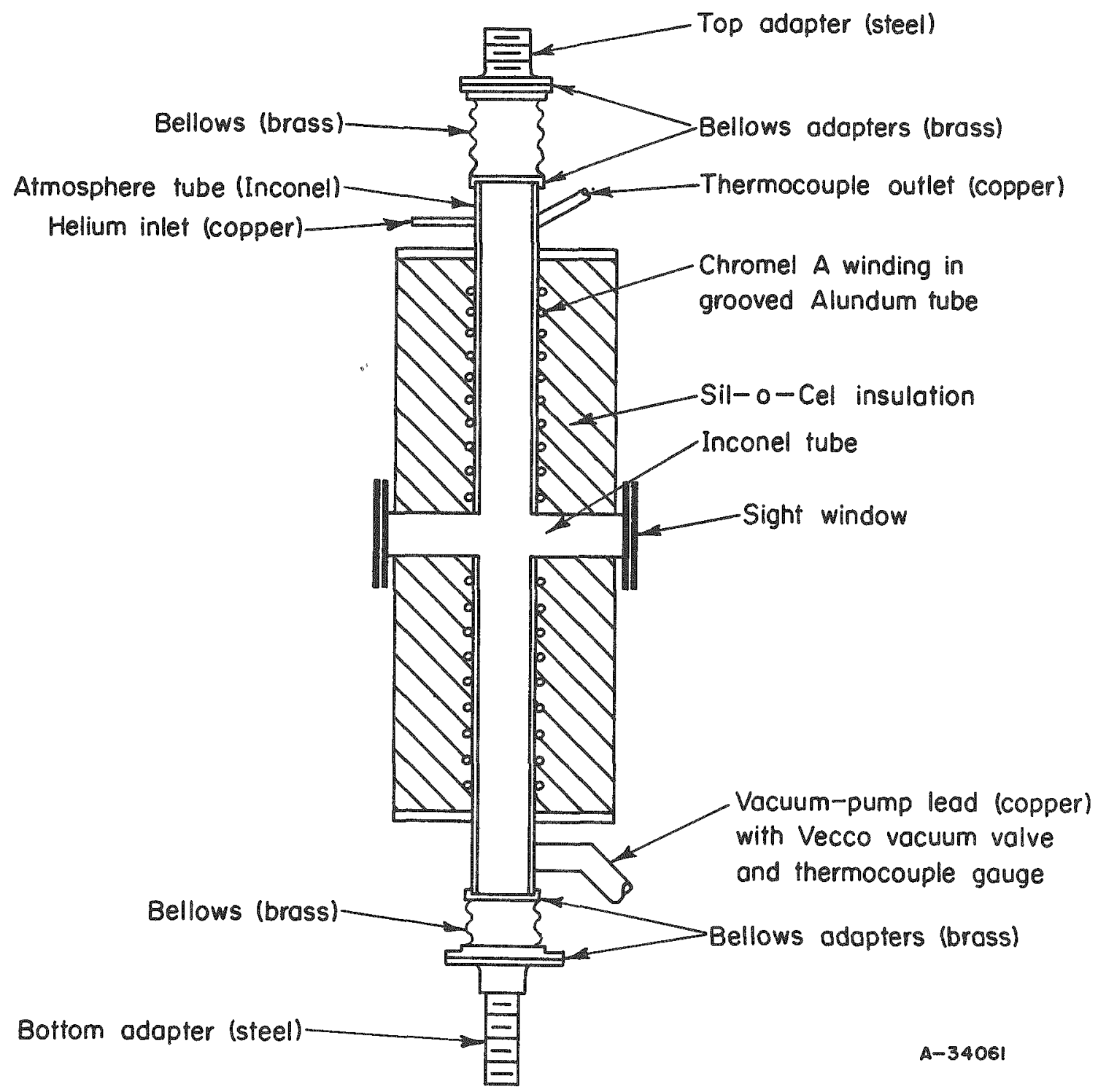

FIGURE 5. SCHEMATIC DRAWING OF INERT-ATMOSPHERE FURNACE USED FOR CREEP AND CREEP-RUPTURE TESTS 
Vacuum-Induction Heating System

The only material available at the start of the program was in the cold-worked condition. It was decided to eliminate the variable of cold work by annealing. Here, again, a vacuum-annealing furnace was required to prevent gaseous contamination of the metal. Moreover, the furnace had to be capable of reaching extremely high temperatures. Figure 6 shows a schematic drawing of the vacuum-induction heating system ultimately developed to anneal tantalum specimens. This equipment was also used for thermal degassing, as is discussed later.

Specimens to be annealed or degassed were suspended inside a clear-fused quartz tube by means of tantalum wire and an Alundum insulator. The wire was attached to a Vycor hook fused to a Vycor sight glass.

Heating of the specimens was accomplished with a 50-kw high-frequency induction unit (Megatherm). The quartz work tube was cooled by water flowing on it from three nozzles located circumferentially around it. A vacuum of the arder of $5 \times 10^{-6} \mathrm{~mm}$ of mercury could be attained (prior to heating) by means of an oil diffusion pump, a forepump, and a liquid-nitrogen cold trap. The pressure of the system was measured with a NRC ionization gage and ionization-gage control. The apparent temperature of the specimens was measured by reflecting an image of them into an optical pyrometer with a mirror attached over the top of the sight glass. This method of measuring the temperature was necessary because a dark metallic film was deposited on the inside wall of the work tube at temperatures above $3700 \mathrm{~F}$, which made direct viewing of the specimen impossible. The true temperatures of the specimens were obtained by adding corrections for the emissivity of tantalum(1) and corrections for the sight glass and mirror. Emissivity corrections for tantalum at observed temperatures of 2200 and $4000 \mathrm{~F}$ were about 200 and $520 \mathrm{~F}$, respectively. The average temperature correction for a Vycor sight glass and mirror was about $80 \mathrm{~F}$.

\section{Creep-Testing Procedure}

Figure 7 shows the shape and dimensions of the creep-test specimens used in this work. Specimens were degreased with acetone and wrapped one and one-half times with 1 -mil-thick tantalum foil to provide additional protection from contamination during testing. Small holes were pierced in the tantalum foil along the edge of the specimen in the reduced section to enable entrapped air to escape.

An extensometer (platinum or tantalum) was fastened to the wrapped specimen to observe the elongation during testing.

Thermocouples were attached to the specimen for controlling and recording the temperature; one of the thermocouples was attached to the center and the other one near the end of the reduced section.

(1) References at end. 


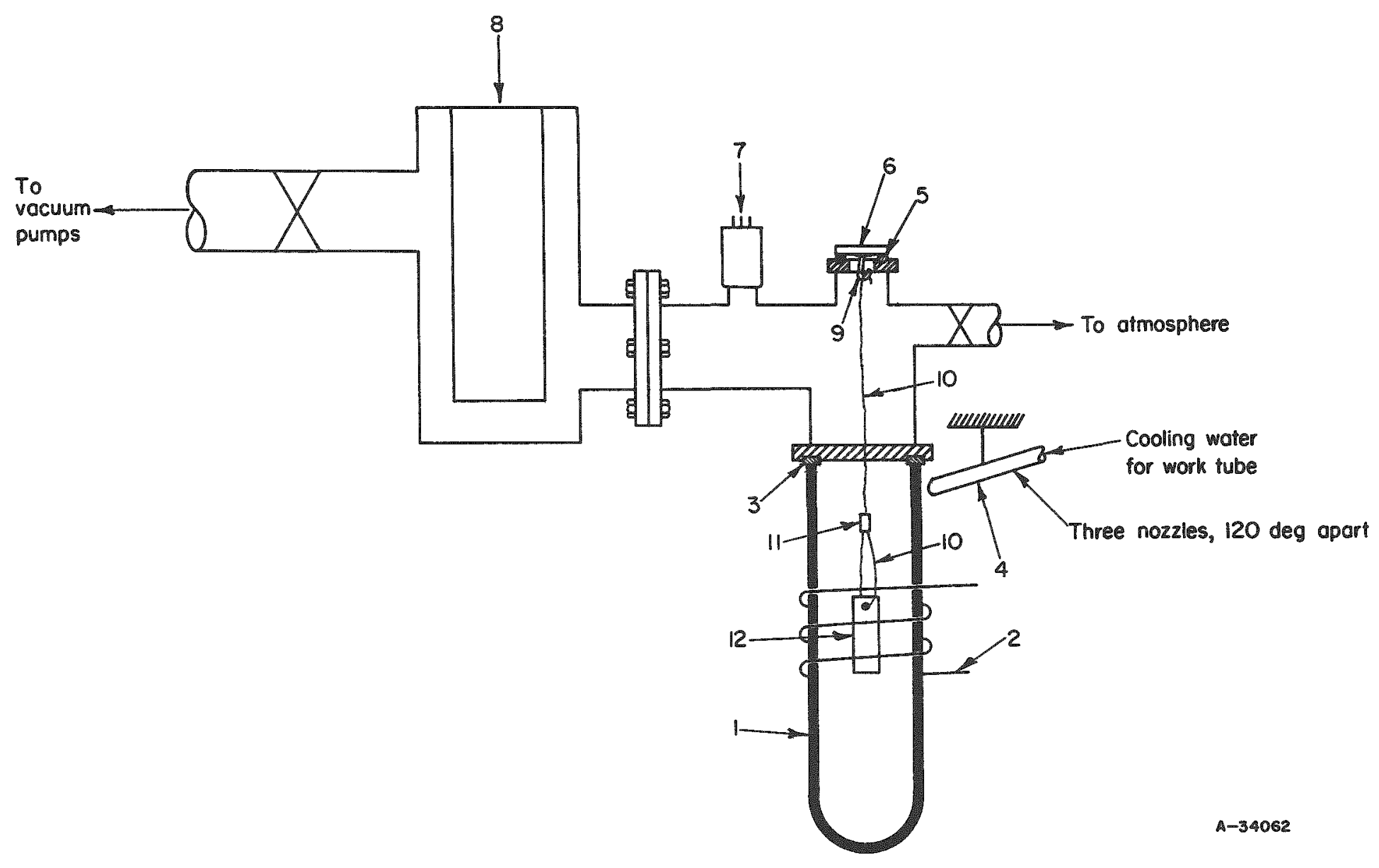

1 - Clear fused quartz work tube ( $50 \mathrm{~mm}$ ID, $2 \mathrm{~mm}$ wall)

2 - Coll of induction heater

3 - O-ring vacuum seal

7 - NRC ionization gauge

8 - Cold trap

9 - Vycor hook (fused to sight glass)

4 - Nozzle for cooling water

5 - O-ring vacuum seal

10 - Tantalum suspension wire for specimen

11 - Alundum four-hole thermocouple protection tube

6 - Vycor sight glass

12 - Tantalum specimen

FIGURE 6. VACUUM INDUCTION HEATING SYSTEM FOR ANNEALING AND DEGASSING TANTALUM 


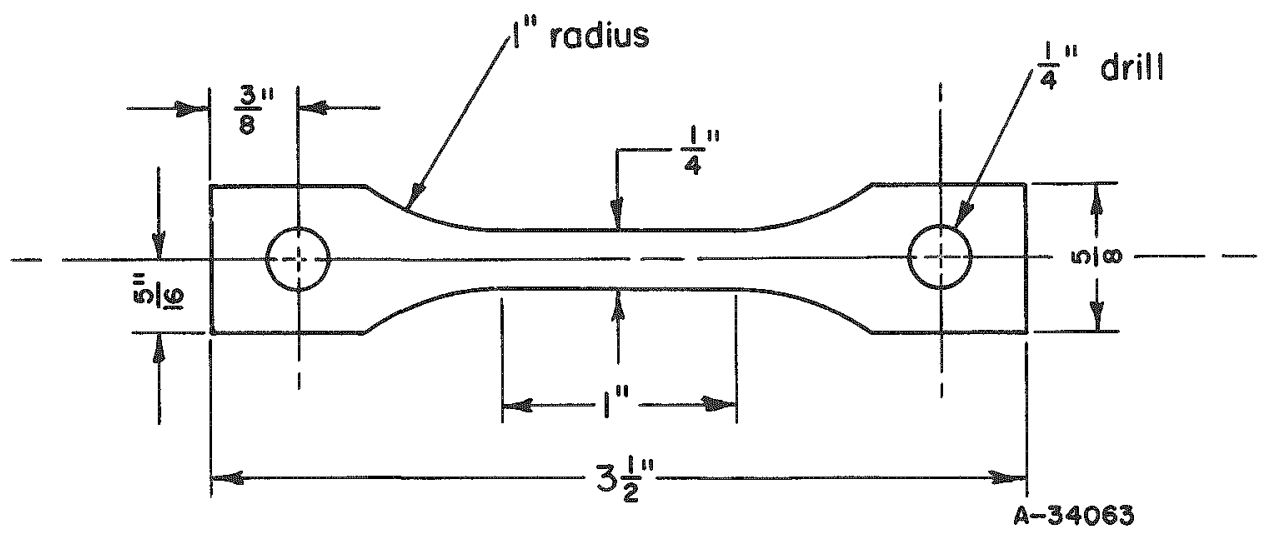

FIGURE 7. 30-MIL STRIP SPECIMEN USED IN CREEP AND CREEP-RUPT URE TESTS

In a typical test a specimen was mounted in the inert-atmosphere creep-testing furnace shown in Figure 5 which was mounted in turn in a Battelle A-type creep-testing frame. The furnace was evacuated until a pressure of $1 \times 10^{-4} \mathrm{~mm}$ of mercury was reached, and a leak rate of $2 \times 10^{-3} \mathrm{~mm}$ of mexcury per min was attained. The furnace was purged four times with helium at $4 \mathrm{psi}$ with the fur nace evacuated to the $1 \times 10^{-4}$ mm of mercury range in between purges; the valve to the vacuum pump was then closed and a helium pressure of 4 psi was maintained during the test period.

The next step in the testing procedure was to heat the specimen to the desired temperature. Any increase in pressure during heating was taken care of by bleeding through the vacuum pump. The load required to produce a predetermined stress was then applied.

The elongation of the specimens was measured daily and from these data timedeformation curves were plotted to obtain the minimum creep rate.

When a test was completed, the load was removed, and the specimen was allowed to cool below $200 \mathrm{~F}$ before removing it from the furnace. After each test the specimen was examined visually for evidence of contamination, its hardness was determined, and in some cases, a chemical analysis was made.

\section{Creep and Stress-Rupture Test Results}

As indicated previously in this report, the creep-testing program was not conducted as originally planned, but was dependent on the procurement of adequate supplies of tantalum sheet. In the course of the work, however, as additional material was obtained and processed, it was possible to accumulate considerable creep data on several types of tantalum with some variations in purity and structure. Among the materials tested were: 
(1) Annealed sheet, from sintered Fansteel tantalum

(2) Thermally degassed sheet from sintered Fansteel tantalum, large grained

(3) Thermally degassed sheet from sintered Kawecki tantalum, fine grained

(4) Annealed sheet from arc-cast Fansteel tantalum

(5) Annealed sheet from sintered Fansteel tantalum exposed to hot flowing sodium

(6) As-rolled and welded sheet from arc-cast Fansteel tantalum.

The experimental work and results are discussed below for each of these groups separately.

Annealed Sintered Tantalum

These tests were conducted at $1200 \mathrm{~F}$ on annealed specimens prepared from Fansteel 30-mil rolled sintered sheet. As discussed previously, annealing was required to eliminate the variable of cold work. The specimens were vacuum annealed by first suspending them inside the quartz work tube of the vacuum-induction heating system shown in Figure 6, and evacuating the system to about $5 \times 10^{-6} \mathrm{~mm}$ of mercury. Then, the specimens were inductively heated to the recrystallization temperature of tantalum, which was determined to be about 2600 to $2800 \mathrm{~F}$, and maintained at temperature for about 8 min before the power was turned off. Firally, after cooling a minimum of $2 \mathrm{hr}$, the specimens were removed from the heating system.

Figure 8 is a photomicrograph showing the fine-grained microstructure of this material; the average grain diameter was about $0.025 \mathrm{~mm}$.

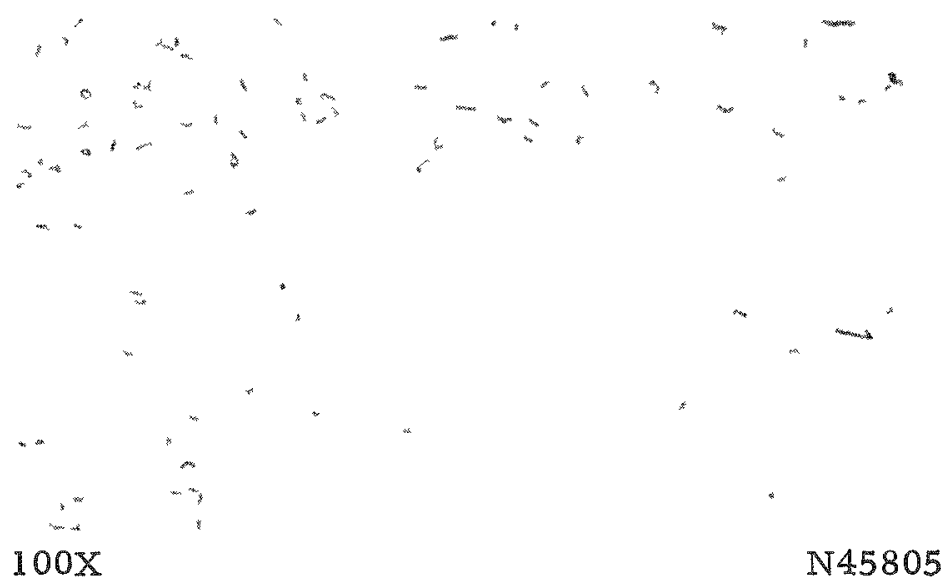

$90 \mathrm{H}_{2} \mathrm{SO}_{4}-10 \mathrm{HF}$ Electrolytic Etch

FIGURE 8. PHOTOMICROGRAPH SHOWING A CROSS SECTION OF 30-MIL ROLLED SINTERED TANTALUM AFTER ANNEALING 8 MIN AT ABOUT 2600 TO $2675 \mathrm{~F}$ 
Table 2 presents the creep and stress-rupture data at $1200 \mathrm{~F}$ in helium on these annealed sintered specimens. Figure 9 gives the design curves and Figure 10 gives curves for stress versus minimum creep rate. Figure 10 also includes curves for degassed coarse-grained sintered sheet and degassed fine-grained sintered sheet which are discussed later.

The results of this sexies of tests indicated that stresses of about 13,000 and 11,500 psi were required to produce 0.5 per cent deformation in 100 and $1000 \mathrm{hr}$, respectively. Assuming that the slopes of the deformation curves shown in Figure 9 remain constant after $1000 \mathrm{hr}$, by extrapolation one might estimate that a stress of about 10,000 psi would produce 0.5 per cent deformation in $10,000 \mathrm{hr}$. The following data are taken from the creep-rupture curve:

$\begin{array}{cc}\text { Rupture Life, } h r & \text { Stress, psi } \\ 10 & 29,000 \\ 100 & 26,000 \\ 1000 & 23,000\end{array}$

Hardness and analyses of gaseous constituents were made before and after creep testing to determine the effectiveness of the furnace atmosphere. The data given below show only a slight increase of about 2 to 3 VHN, while the interstitials, particularly oxygen, increased substantially.

Time

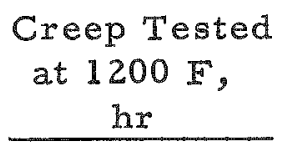

(6)

1326

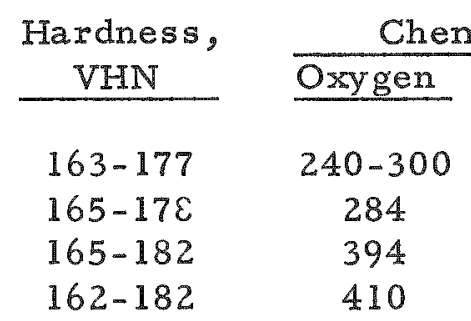

Chemical Analyses, ppm

$\begin{array}{cc}\text { Hydrogen } & \text { Nitrogen } \\ 1 & \\ 11 & 150 \\ 16 & -- \\ 1.6 & 170 \\ & 170\end{array}$

Based on these findings, the furnace atmosphere contributed to the increase in contamination level of the specimens. However, it is believed that this had no significant effect on the minimum creep rate of tantalum.

Thermally Degassed Coarse-Grained Sintered Tantalum

Commercial tantalum that was available early in this investigation was generally very high in gaseous impurities. However, since the findings at Los Alamos pointed out the need for determining the strength of material of low gas content, emphasis was placed on obtaining low-oxygen-content tantalum by thermal degassing.

The thermal-degassing treatment of these specimens, and others to be discussed later, was practically the same as that described earlier for annealing. The most significant difference was that of temperature and time. Other investigators have found that a temperature of $4350 \mathrm{~F}$ for about $1 \mathrm{hr}$ was required to degas tantalum successfully. (2) 
TABLE 2. CREEP DATA ON ROLLED AND ANNEALED SINTERED TANTALUM TESTED AT 1200 F IN A HELIUM ATMOSPHERE

\begin{tabular}{|c|c|c|c|c|c|c|c|c|c|c|c|c|}
\hline \multirow[b]{2}{*}{ Specimen } & \multirow{2}{*}{$\begin{array}{c}\text { Stress, } \\
\text { psi }\end{array}$} & \multirow{2}{*}{$\begin{array}{l}\text { Time in } \\
\text { Progress } \\
\text { hr }\end{array}$} & \multicolumn{7}{|c|}{ Time to Reach Indicated Per Cent Deformation, $\mathrm{hr}$} & \multirow{2}{*}{$\begin{array}{c}\text { Initial } \\
\text { Deformation, } \\
\text { per cent }\end{array}$} & \multirow{2}{*}{$\begin{array}{c}\text { Total } \\
\text { Deformation, } \\
\text { per cent }\end{array}$} & \multirow{2}{*}{$\begin{array}{c}\text { Minimum } \\
\text { Creep Rate, } \\
\text { per cent per hr }\end{array}$} \\
\hline & & & 0.1 & 0.2 & 0.5 & 1.0 & 2 & 5 & 10 & & & \\
\hline $2-16$ & 32,000 & $3.6^{(a)}$ & - & - & - & -- & $-\infty$ & $\infty$ & 0.5 & 5.42 & 88.5 & 9.9 \\
\hline $2-6$ & 28,000 & $16.0^{(a)}$ & - & - & - & - & -- & 0.1 & 1.7 & 3.20 & 65.5 & 1.1 \\
\hline $2 \approx 2$ & 24,000 & $460.8^{(a)}$ & -- & $-\infty$ & -- & -- & 0.2 & 2.8 & 12.0 & 1.16 & 73.1 & 0.065 \\
\hline $2-10$ & 20,000 & 475.4 & -- & 0.4 & 1.5 & 2.2 & 3.6 & 69 & $500^{(b)}$ & 0.124 & 9.5 & 0.011 \\
\hline $2 \infty 4$ & 15,000 & 1010.6 & -- & 4.0 & 13.0 & 46.5 & 775 & $-\infty$ & $=$ & (c) & 2.15 & 0.0004 \\
\hline $2-9$ & 12,500 & 1515.4 & -- & 5.0 & 11.0 & 33.0 & 1275 & -- & -- & (c) & 2.18 & 0.0003 \\
\hline $2-19$ & 12,500 & 1850.0 & 88 & $2300^{(b)}$ & $-\infty$ & $\ldots$ & $-\infty$ & - & - & 0.025 & 0.14 & 0.000045 \\
\hline $5-9$ & 12,500 & 1325.6 & -- & 0.8 & 3.3 & 7.5 & - & $-\infty$ & -- & 0.104 & 1.86 & 0.00024 \\
\hline $2 \approx 5$ & 10,000 & 1368.7 & $1800(b)$ & -- & -- & $-\infty$ & $-\infty$ & -- & -- & (c) & 0.081 & 0.00005 \\
\hline
\end{tabular}

(a) Specimen failed at indicated time.

(b) Estimated time.

(c) Negative deformations obtained because specimen was slightly bent. 


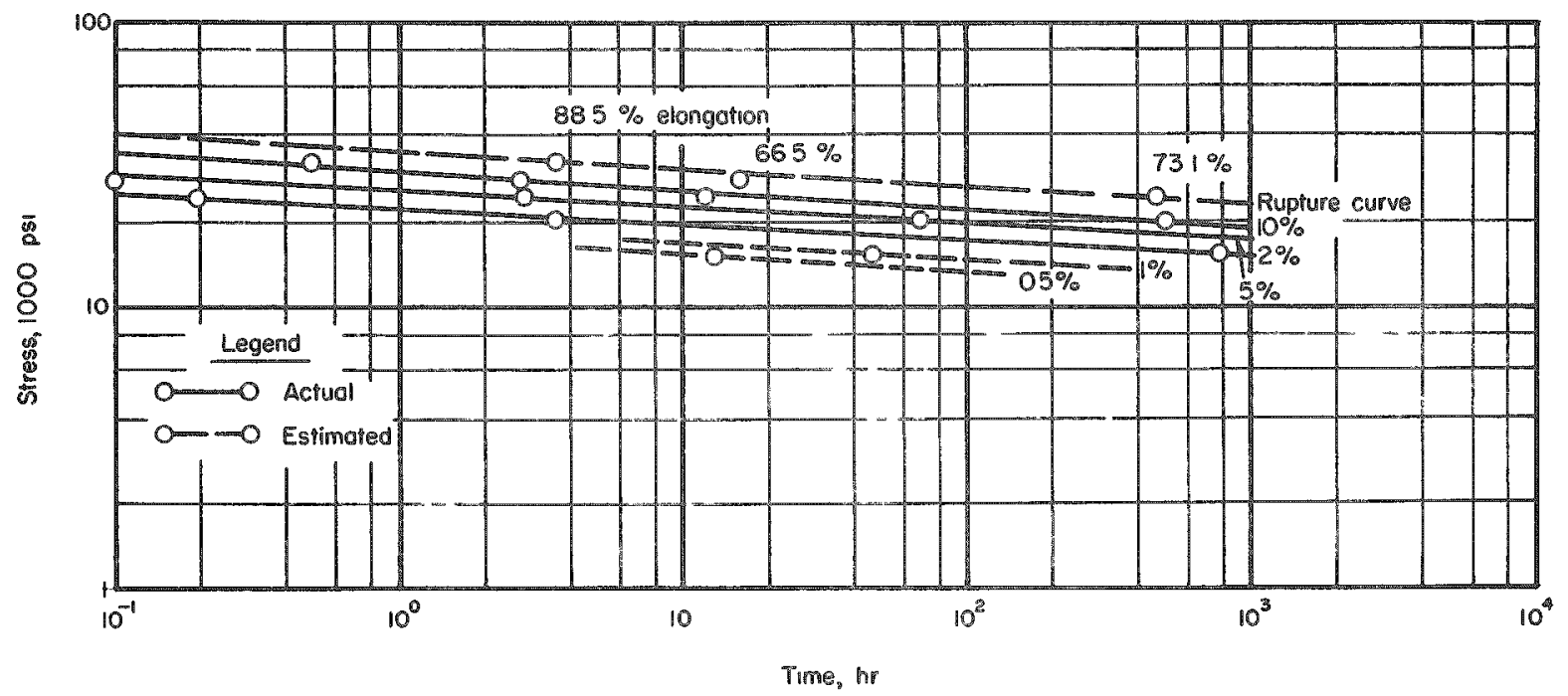

FIGURE 9. DESIGN DATA ON ANNEALED SINTERED TANTALUM SHEET TESTED AT 1200 F IN HELIUM

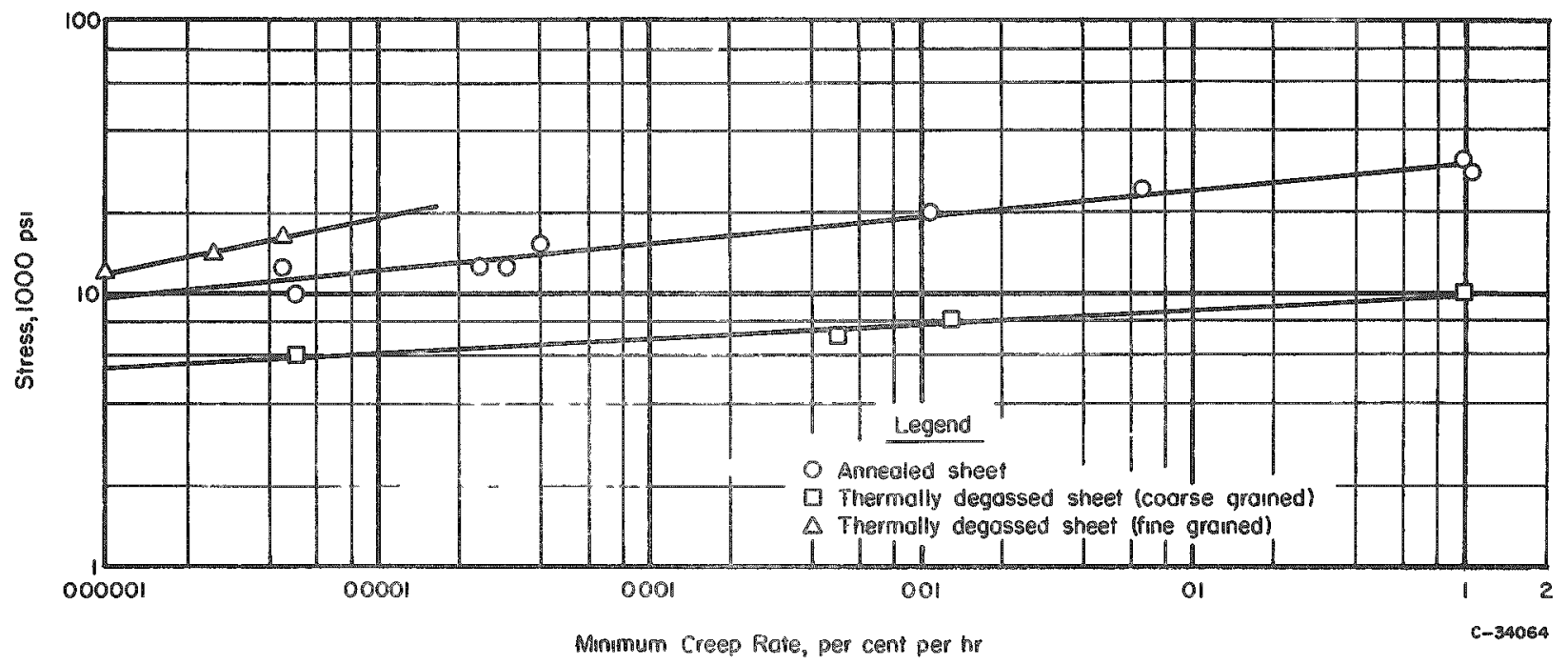

FIGURE 10. STRESS VERSUS MINIMUM CREEP RATE FOR SINTERED TANTALUM TESTED AT 1200 FIN HELIUM 
In the present tests, the 30-mil sheet specimens produced from high-gas-content sintered tantalum were thermally degassed for about $5 \mathrm{hr}$ at approximately 4500 to $4800 \mathrm{~F}$; the final pressure in the system was $2 \times 10^{-5} \mathrm{~mm}$ of mercury.

Figure 11 illustrates the extremely large-grained structure of this material, which has an average grain diameter greater than $1 \mathrm{~mm}$. Such grain growth appeared to be unavoidable in degassing tantalum by this method.

$100 \mathrm{X}$

N45807

$90 \mathrm{H}_{2} \mathrm{SO}_{4}-10 \mathrm{HF}$ Electrolytic Etch

FIGURE 11. CROSS SECTION OF A 30-MIL STRIP SPECIMEN OF

ROLLED SINTERED TANTALUM THERMALLY

DEGASSED 5 HR AT 4500 TO $4800 \mathrm{~F}$

The creep and stress-rupture data for this material are summarized in Table 3. Minimum-creep-rate information is shown in Figure 10. Design curves plotted from these tests are shown in Figure 12. These data indicated that stresses of about 6500 and 5500 psi produced 0.5 per cent deformation in 100 and $1000 \mathrm{hr}$. By extrapolation of the curve in Figure 12, one would estimate that a deformation of 0.5 per cent would be produced by a stress of only $4800 \mathrm{psi}$ in $10,000 \mathrm{hr}$. The estimated rupture curve, also shown in Figure 12, gives the following rupture lives:

$\begin{array}{cr}\text { Rupture Life, hro } & \text { Stress, psi } \\ 10 & 10,300 \\ 100 & 9,400 \\ 1000 & 8,400\end{array}$

This material exhibited the lowest creep resistance of the groups investigated. It is believed that the excessively large grains resulting from the high-temperature degassing treatment were primarily responsible for the low strength. A comparison of the strength of this degassed material with that of annealed material (see Figure 10) shows that the annealed material was about twice as strong. For example, a stress of about 6000 psi produced a minimum creep rate of about 0.00005 per cent per hr for the degassed laxge-grained specimens, whereas a stress of about 12,000 psi was required to produce the same creep rate for the annealed specimens. 
TABLE 3. CREEP DATA ON THERMALLY DEGASSED COARSE -GRAINED 30-MIL ROLLED SINTERED TANTALUM TESTED AT 1200 F IN A HELIUM ATMOSPHERE

\begin{tabular}{|c|c|c|c|c|c|c|c|c|c|c|c|c|}
\hline \multirow[b]{2}{*}{ Specimen } & \multirow{2}{*}{$\begin{array}{c}\text { Stress, } \\
\text { psi }\end{array}$} & \multirow{2}{*}{$\begin{array}{l}\text { Time in } \\
\text { Progress, } \\
\text { hr }\end{array}$} & \multicolumn{7}{|c|}{ Time so Reach Indicated Per Cent Deformation, hr } & \multirow{2}{*}{$\begin{array}{c}\text { Inivial } \\
\text { Deformation, } \\
\text { per cene }\end{array}$} & \multirow{2}{*}{$\begin{array}{c}\text { Total } \\
\text { Deformation, } \\
\text { per cent }\end{array}$} & \multirow{2}{*}{$\begin{array}{c}\text { Minimum } \\
\text { Creep Rate, } \\
\text { per cent per hr }\end{array}$} \\
\hline & & & 0.1 & 0.2 & 0.5 & 1.0 & 2 & 5 & 10 & & & \\
\hline $4-7$ & 20,000 & 0 & $-\infty$ & -- & -- & - & -- & -- & $-\infty$ & $-\infty$ & 13 & $-\infty$ \\
\hline $4 \infty 6$ & 10,000 & $21.1^{(a)}$ & -- & 0.1 & 0.28 & 0.55 & 0.9 & 2.2 & 4 & 0.063 & 40.6 & 2.3 \\
\hline $4 \oplus 3$ & 8,000 & 651.7 & 0.15 & 0.45 & 1.3 & 2.6 & 27 & 256 & 518 & 0.056 & 11.7 & 0.013 \\
\hline $4-4$ & 7,000 & $670.5^{(a)}$ & 1.5 & 7.5 & 25 & 78 & 127 & 290 & -- & 0.030 & 15.5 & 0.005 \\
\hline $4-5$ & 6,000 & 1121.1 & 21 & 125 & $-\infty$ & $-\infty$ & -- & -- & $=$ & 0.028 & 0.285 & 0.00005 \\
\hline
\end{tabular}

(a) Failed at time indicated. 


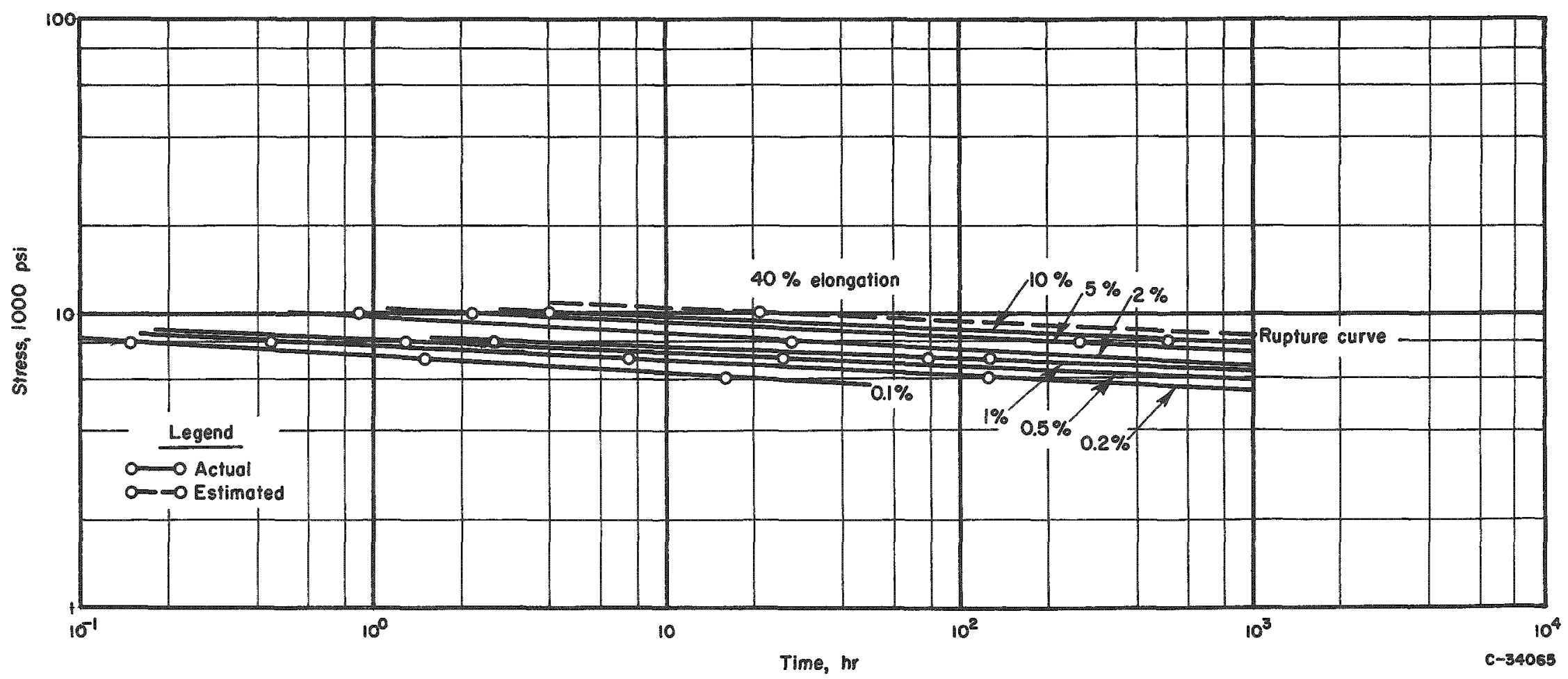

FIGURE 12. DESIGN DATA ON THERMALIY DEGASSED COARSE-GRAINED SINTERED TANTALUM SHEET TESTED AT 1200 F IN HELIUM 
Hardnes and analytical data obtained for this thermally degassed sintered tantalum before and after creep testing at $1200 \mathrm{~F}$ were as follows:

\begin{tabular}{|c|c|c|c|c|c|}
\hline & Hardness, & & hemical A & ysis, ppr & \\
\hline & VHN & Oxygen & Hydrogen & Nitrogen & Carbon \\
\hline Before creep testing & $89-115$ & 2 & 0.2 & 50 & $<10$ \\
\hline After creep testing & $97-130$ & 100 & 14 & 80 & 10 \\
\hline
\end{tabular}

As in the case of the sintered and annealed specimens mentioned previously, the degassed specimens were also contaminated by the furnace atmosphere during testing. Here, again, it is believed that this increase in the level of contamination had no significant effect upon the creep resistance.

\section{Thermally Degassed Fine-Grained}

Sintered Tantalum

In the LAMPRE environment, the plutonium fuel removes both oxygen and nitrogen from the metal, presumably with no change in the grain structure. Therefore, the large-grained material discussed in the preceding section does not exactly reproduce the material which exists in the reactor. It was anticipated that the following series of operations would result in fine-grained degassed tantalum:

(1) Solid-state purification by thermal degassing with vacuum-induction heating to form a large-grained structure

(2) Severe cold working to provide a large number of nuclei for subsequent recrystallization

(3) Recrystallization annealing in vacuum to produce a fine-grained structure.

In order to implement this procedure, it was first necessary to determine the recrystallization behavior of large-grained thermally degassed tantalum after cold rolling various degrees. These studies were made with arc-cast tantalum. Annealing temperatures of 2350 and $2650 \mathrm{~F}$, an annealing time of $10 \mathrm{~min}$, cold reductions of 57 through 95 per cent, and unidirectional versus alternate cross rolling were investigated. Fairly satisfactory grain refinement occurred with a recrystallization anneal at $2650 \mathrm{~F}$, after cold reductions, largely in one direction, of 80 per cent and over. The average grain diameter obtained was about $0.045 \mathrm{~mm}$, as compared with $0.035 \mathrm{~mm}$ on annealed commercial arc-cast tantalum.

In order to obtain 30-mil degassed fine-grained sintered tantalum, it was necessary to thermally degas a 150-mil-thick bar of the Kawecki material according to the procedure previously discussed. Figures 13 and 14 show the microstructure of this material after thermal degassing for 20 and $60 \mathrm{~min}$ at about 4500 and $4650 \mathrm{~F}$, respectively. The average grain diameter was $0.070 \mathrm{~mm}$ for the specimen shown in Figure 13 and $0.050 \mathrm{~mm}$ for that shown in Figure 14. However, grains as large as $0.300 \mathrm{~mm}$ were present at the surface of these specimens. 


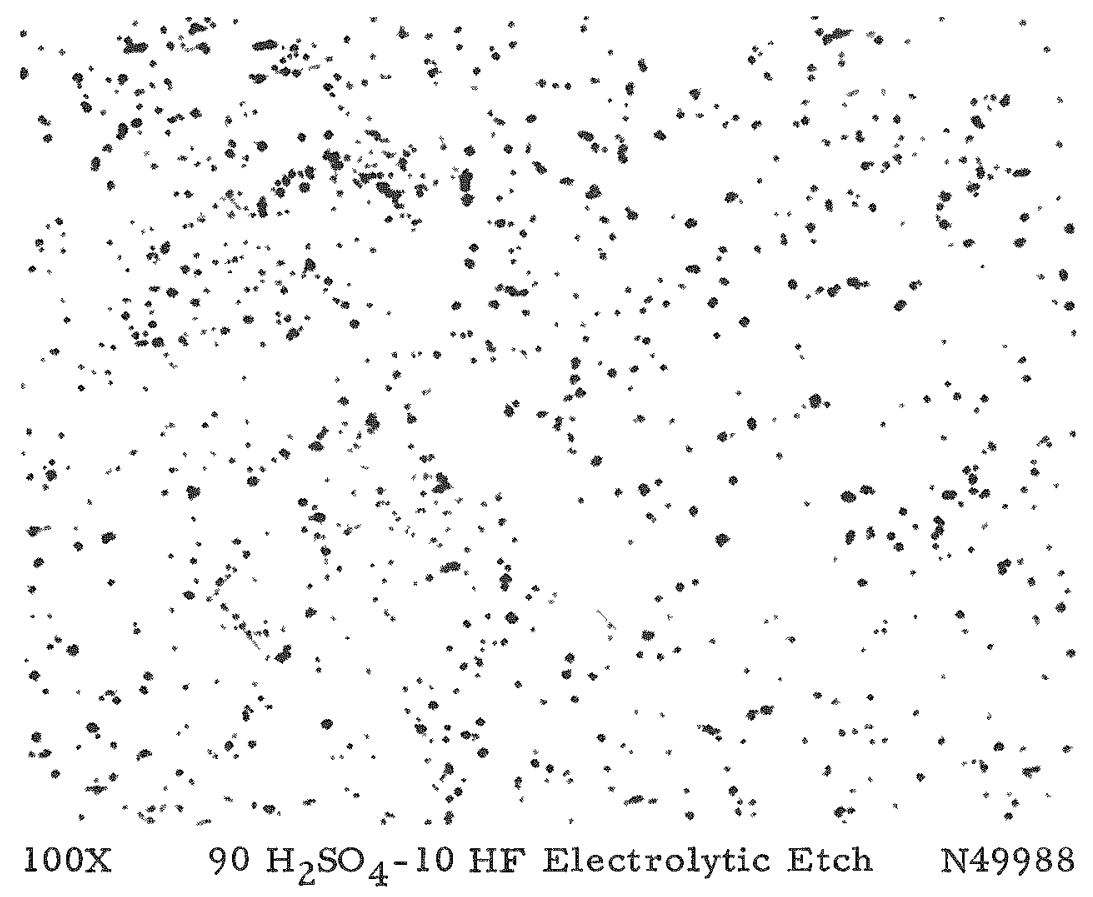

FIGURE 13. 150-MIL SINTERED TANTALUM AFTER THERMAL DEGASSING 20 MIN AT ABOUT $4500 \mathrm{~F}$

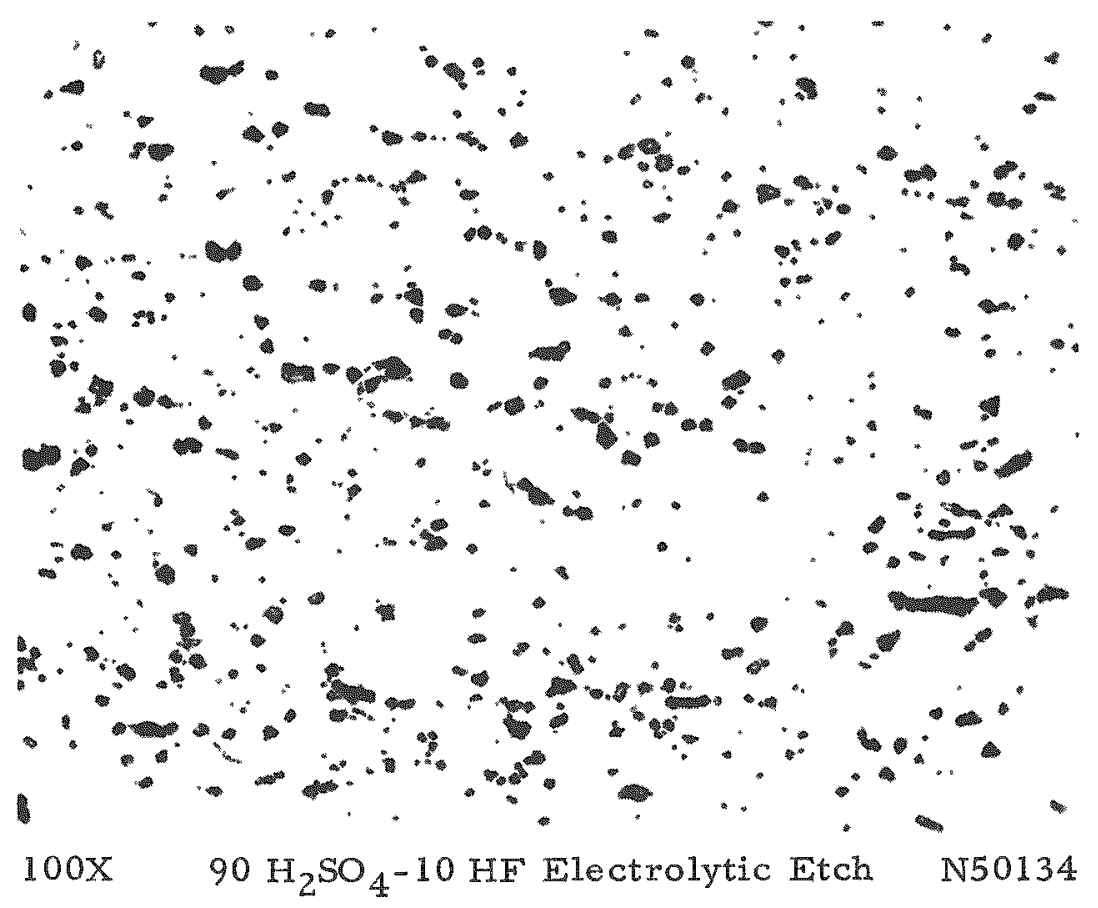

FIGURE 14. 150-MIL SINTERED TANTALUM AFTER THERMAL DEGASSING 60 MIN AT ABOUT $4650 \mathrm{~F}$ 
These degassed tantalum bars were cold rolled to 30 mils ( 80 per cent reduction) and then machined into creep specimens. Next, the creep specimens were given a recrystallization anneal. Figure 15 shows the microstructure of the degassed specimen shown in Figure 13, after cold working and vacuum annealing at $2750 \mathrm{~F}$ for $10 \mathrm{~min}$. Figure 16 illustrates the microstructure of the degassed specimen shown in Figure 14, after cold rolling and vacuum annealing at $2800 \mathrm{~F}$ for $15 \mathrm{~min}$. The average grain diameters obtained after the recrystallization anneal were 0.025 and $0.035 \mathrm{~mm}$ for the specimens shown in Figures 15 and 16 , respectively.

Hardness and analytical data for the thermally degassed fine-grained sintered tantalum before and after creep testing are as follows:

\begin{tabular}{|c|c|c|c|c|c|}
\hline & \multirow{2}{*}{$\begin{array}{c}\text { Hardness, } \\
\text { VHIN } \\
\end{array}$} & \multicolumn{4}{|c|}{ Chemical Analysis, ppm } \\
\hline & & Oxygen & Hydrogen & Nitrogen & Carbon \\
\hline Before creep testing & $66-81$ & $10-16$ & 0.7 & 20 & $20-30$ \\
\hline $\begin{array}{l}\text { After creep testing } \\
1200 \mathrm{hr} \text { at } 1200 \mathrm{~F}\end{array}$ & $76-98$ & $60-140$ & $4-6$ & $30-50$ & $10-20$ \\
\hline
\end{tabular}

Creep tests were conducted at $1200 \mathrm{~F}$ in helium on this low-gas-content finegrained sintered tantalum, which approximates the condition of tantalum after exposure to the fuel in the LAMPRE environment. The creep-test results, which are summarized in Table 4, indicate that a stress of about 16,000 psi was required to produce 0.2 per cent deformation in $1000 \mathrm{hr}$. In the absence of sufficient data for plotting design curves, it is difficult to predict the stress level required to produce 0.5 per cent deformation in $10,000 \mathrm{hr}$; however, as a rough approximation, one might estimate that the stress level would be between 12,000 and 14,000 psi. A comparison of the minimum creep-rate curves (Figure 10) for sintered tantalum in the annealed condition, thermally degassed coarse-grained condition, and thermally degassed fine-grained condition shows that the latter matexial is far superior to the other two. Several possible explanations for this phenomenon come to mind. First, it is believed that grain size had a substantial effect on creep strength, which would account for the superior creep behavior of the finegrained high-purity tantalum compared with that of the coarse-grained high-purity material. Secondly, the higher strength of the fine-grained degassed tantalum, as compared with that of the sintered and annealed material, may have resulted from a reduction in porosity during the high-temperature degassing treatment.

Annealed Arc-Cast Tantalum

Another series of creep tests was conducted on annealed specimens that were fabricated from Fansteel arc-cast tantalum sheet. This material was received in the cold-worked condition. Therefore, the specimens were annealed, using the same procedure discussed earlier, for $18 \mathrm{~min}$ at about $2650 \mathrm{~F}$. A photomicrograph of this annealed tantalum is shown in Figure 17. The average grain diameter was $0.035 \mathrm{~mm}$.

Creep tests on this material were run at three different temperature levels: 900 , 1200 , and $1500 \mathrm{~F}$. Time did not permit extensive testing at 900 and $1500 \mathrm{~F}$; therefore, in order to obtain as much information as possible from these tests, the stress was increased after pexiods of about $300 \mathrm{hr}$. Although this method of testing probably does not 


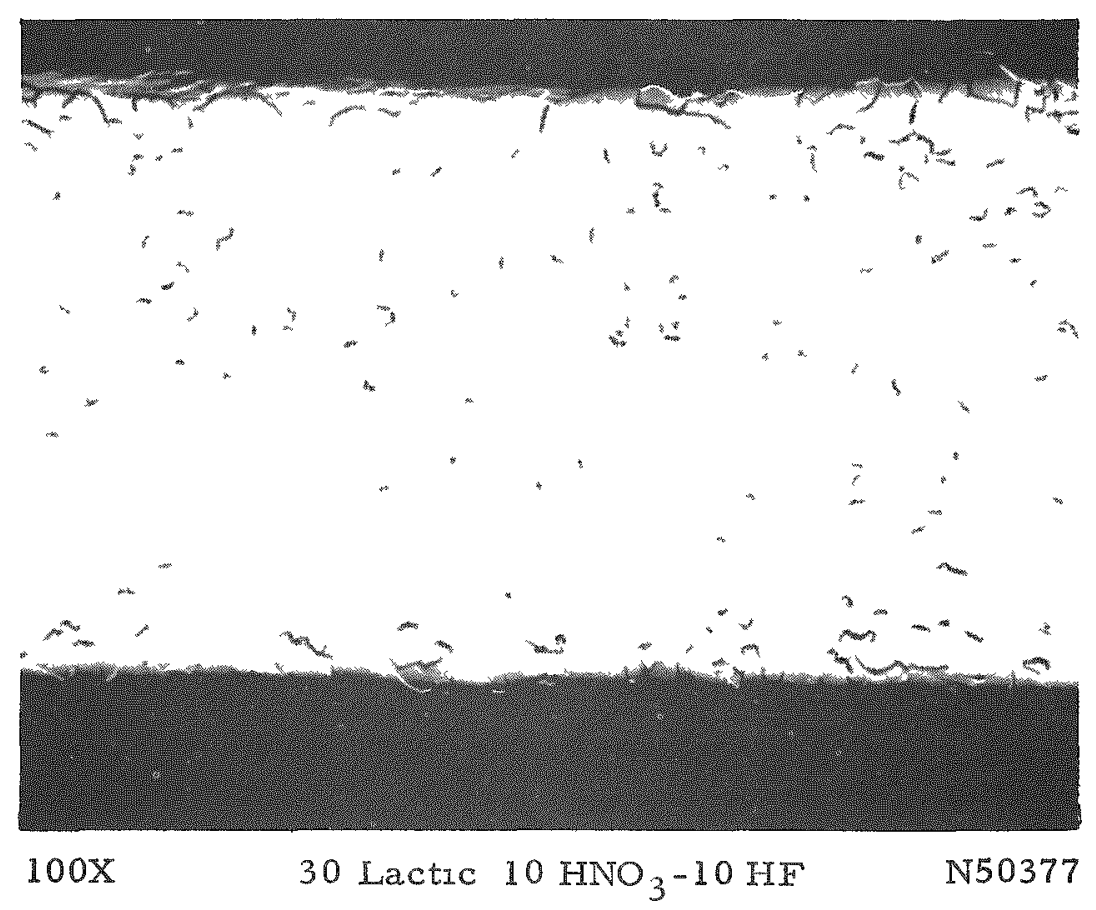

FIGURE 15. CROSS SECTION OF THE TANTALUM SHOWN IN FIGURE 13 AFTER COLD ROLLING TO 30 MILS AND ANNEALING 10 MIN AT ABOUT $2750 \mathrm{~F}$

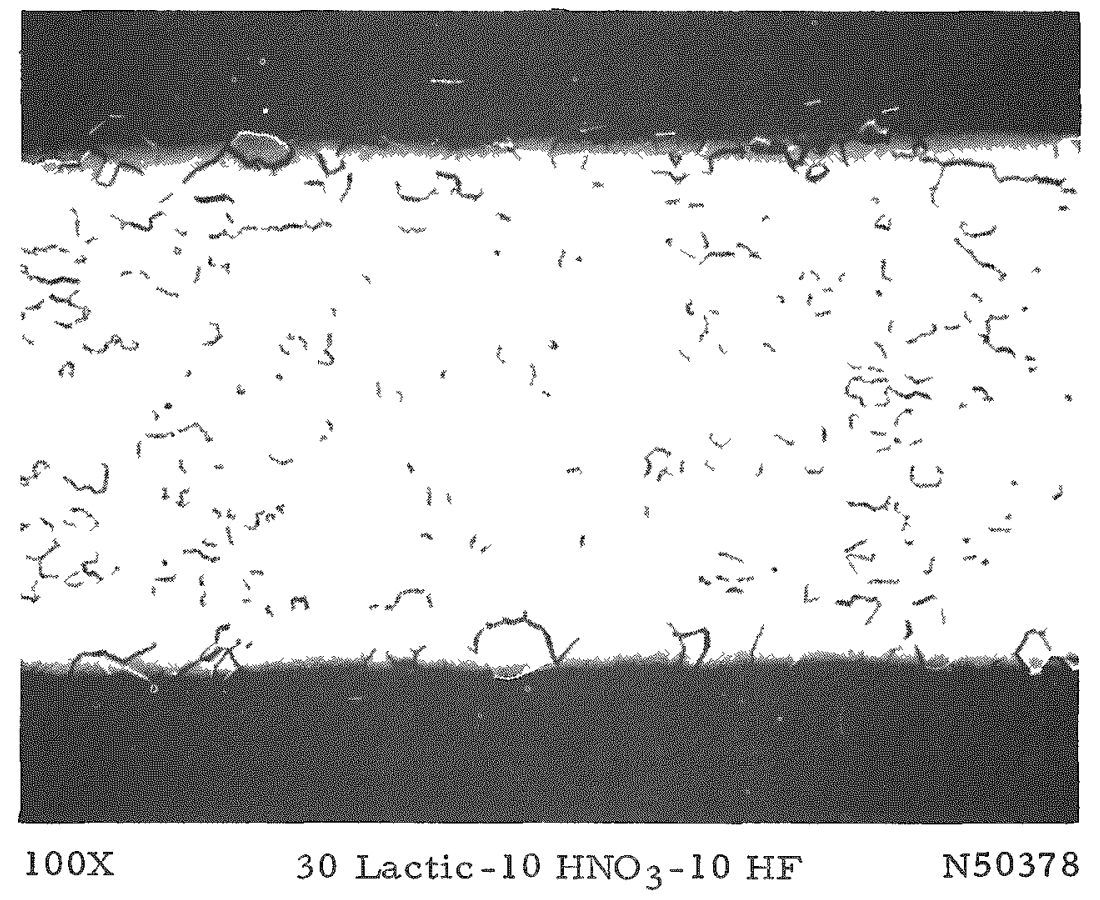

FIGURE 16. CROSS SECTION OF THE TANT ALUM SHOWN IN FIGURE 14 AFTER COLD ROLIING TO 30 MILS AND ANNEALING $15 \mathrm{MIN}$ AT ABOUT $2800 \mathrm{~F}$ 
TABLE 4. CREEP DATA ON THERMALLY DEGASSED FINE GRAINED SINTERED TANTALUM SHEET TESTED AT 1200 F IN HELIUM

\begin{tabular}{|c|c|c|c|c|c|c|c|}
\hline Specimen & $\begin{array}{c}\text { Stress, } \\
\text { psi }\end{array}$ & $\begin{array}{c}\text { Time in } \\
\text { Progress, } \\
\text { hr }\end{array}$ & $\begin{array}{c}\text { Time } \\
\text { Per Ce: } \\
0.1\end{array}$ & $\begin{array}{l}\text { icated } \\
\text { ion, hr } \\
0.2\end{array}$ & $\begin{array}{c}\text { Initial } \\
\text { Deformation, } \\
\text { per cent }\end{array}$ & $\begin{array}{c}\text { Total } \\
\text { Deformation, } \\
\text { per cent }\end{array}$ & $\begin{array}{c}\text { Minimum } \\
\text { Creep Rate } \\
\text { per cent per hr }\end{array}$ \\
\hline $21-B 1$ & 10,000 & 960.7 & -- & -- & 0.051 & 0.090 & Nil \\
\hline $25-4$ & 12,000 & 1200.0 & -- & $-\infty$ & 0.012 & 0.098 & 0.00001 \\
\hline $25-3$ & 14,000 & 1032.3 & 90 & $-\infty$ & 0.058 & 0.158 & 0.000025 \\
\hline $21-B 2$ & 16,000 & 1001.8 & 0.0 & 965 & 0.120 & 0.201 & 0.00004 \\
\hline
\end{tabular}


produce exactly the same results as the standard method, it does give an indication of the strength at the two temperatures.

$100 \mathrm{X}$

N45808

$90 \mathrm{H}_{2} \mathrm{SO}_{4}-10 \mathrm{HF}$ Electrolytic Etch

FIGURE 17. PHOTOMICROGRAPH OF A CROSS SECTION OF 30-MIL ROLLED ARC-CAST TANTALUM AFTER ANNEALING 18 MIN AT ABOUT $2650 \mathrm{~F}$

Creep data and curves of stress versus minimum creep rate are presented in Table 5 and Figure 18, respectively. The results indicate that at $1200 \mathrm{~F}$ this material was stronger than the annealed sintered tantalum discussed previously and the thermally degassed coarse-grained sintered tantalum. For example, a stress of 15,000 psi produced a minimum creep rate of 0.00005 per cent per hr for the annealed arc-cast tantalum, while a stress of only 10,000 psi caused the same creep rate for the annealed sintered tantalum. The difference in the strengths of the two materials apparently is the result of the method of production, since the chemical analysis and grain size of the two were about the same.

A comparison of the strengths at 1200 and $1500 \mathrm{~F}$ indicates that at the lower temperature the strength of the annealed arc-cast tantalum is about one and one-half times greater. However, it should be pointed out that the results for the tests at 900 and $1500 \mathrm{~F}$ are based on only one test at each temperature.

Hardness and analytical data on the annealed arc-cast tantalum prior to and after creep testing are giver below:

\begin{tabular}{|c|c|c|c|c|c|}
\hline & \multirow{2}{*}{$\begin{array}{c}\text { Hardness, } \\
\text { VHN } \\
\end{array}$} & \multicolumn{4}{|c|}{ Analysis Results, ppm } \\
\hline & & Oxygen & Hydrogen & Nitrogen & Carbon \\
\hline Before creep testing & $169-183$ & 214 & 0.3 & 150 & 10 \\
\hline $\begin{array}{c}\text { After creep testing } \\
984 \mathrm{hr} \text { at } 1200 \mathrm{~F}\end{array}$ & $182-190$ & 490 & 0.3 & 160 & 20 \\
\hline
\end{tabular}


TABLE 5. CREEP DATA ON ANNEALED ARC-CAST TANTALUM TESTED AT 900, 1200, AND 1500 F IN A HELIUM ATMOSPHERE

\begin{tabular}{|c|c|c|c|c|c|c|c|c|c|c|}
\hline \multirow[b]{2}{*}{ Specimen } & \multirow{2}{*}{$\begin{array}{c}\text { Temperature, } \\
\text { F }\end{array}$} & \multirow{2}{*}{$\begin{array}{l}\text { Stress, } \\
\text { psi }\end{array}$} & \multirow{2}{*}{$\begin{array}{l}\text { Time in } \\
\text { Progress, } \\
\text { hr }\end{array}$} & \multicolumn{4}{|c|}{$\begin{array}{l}\text { Time to Reach Indicated } \\
\text { Per Cent Deformation, hr }\end{array}$} & \multirow{2}{*}{$\begin{array}{c}\text { Initial } \\
\text { Deformation, } \\
\text { per cent }\end{array}$} & \multirow{2}{*}{$\begin{array}{c}\text { Total } \\
\text { Deformation, } \\
\text { per cent }\end{array}$} & \multirow{2}{*}{$\begin{array}{c}\text { Minimum } \\
\text { Creep Rate, } \\
\text { per cent per hr }\end{array}$} \\
\hline & & & & 0.1 & 0.2 & 0.5 & 1.0 & & & \\
\hline $7 A-10$ & 1200 & 17,500 & 1249.1 & 3 & 7 & 20 & 145 & 0.030 & 1.51 & 0.00021 \\
\hline $7 A-4$ & 1200 & 15,000 & 1631.7 & 12 & 155 & -- & - & 0.045 & 0.258 & 0.00002 \\
\hline $7 A-6$ & 1200 & 15,000 & 1170.3 & 13 & 33 & $1900^{(a)}$ & -- & 0.033 & 0.445 & 0.00008 \\
\hline $7 A-11$ & 1200 & 12,500 & 984.0 & $-\infty$ & -- & - & - & 0.053 & 0.070 & Nil \\
\hline $7 A-17$ & 900 & 20,000 & 241.5 & -- & -- & -- & -- & 0.036 & 0.048 & Ni1 \\
\hline Ditto & 900 & 25,000 & 286.5 & -- & - & -- & -- & $-\infty$ & 0.074 & Ni1 \\
\hline$"$ & 900 & 30,000 & 336.2 & 564 & - & -- & - & -- & 0.102 & 0.00004 \\
\hline " & 900 & 40,000 & 813.2 & -- & 892 & 950 & 1677.4 & - & 0.994 & 0.00048 \\
\hline $7 A-18$ & 1500 & 5,000 & 318.5 & $-\cdots$ & -- & -- & $\cdots$ & 0.008 & (b) & Ni1 \\
\hline Ditto & 1500 & 6.000 & 286.3 & -- & - & -- & -- & -- & (b) & NiI \\
\hline$\because$ & 1500 & 8,000 & 336.1 & -- & -- & -- & -- & - & (b) & Ni1 \\
\hline$"$ & 1500 & 10,000 & 860.0 & - & - & -. & $-\infty$ & - & 0.081 & 0.00003 \\
\hline
\end{tabular}

(a) Estimated time.

(b) Negative values obtained for deformation because of specimen being bent. 


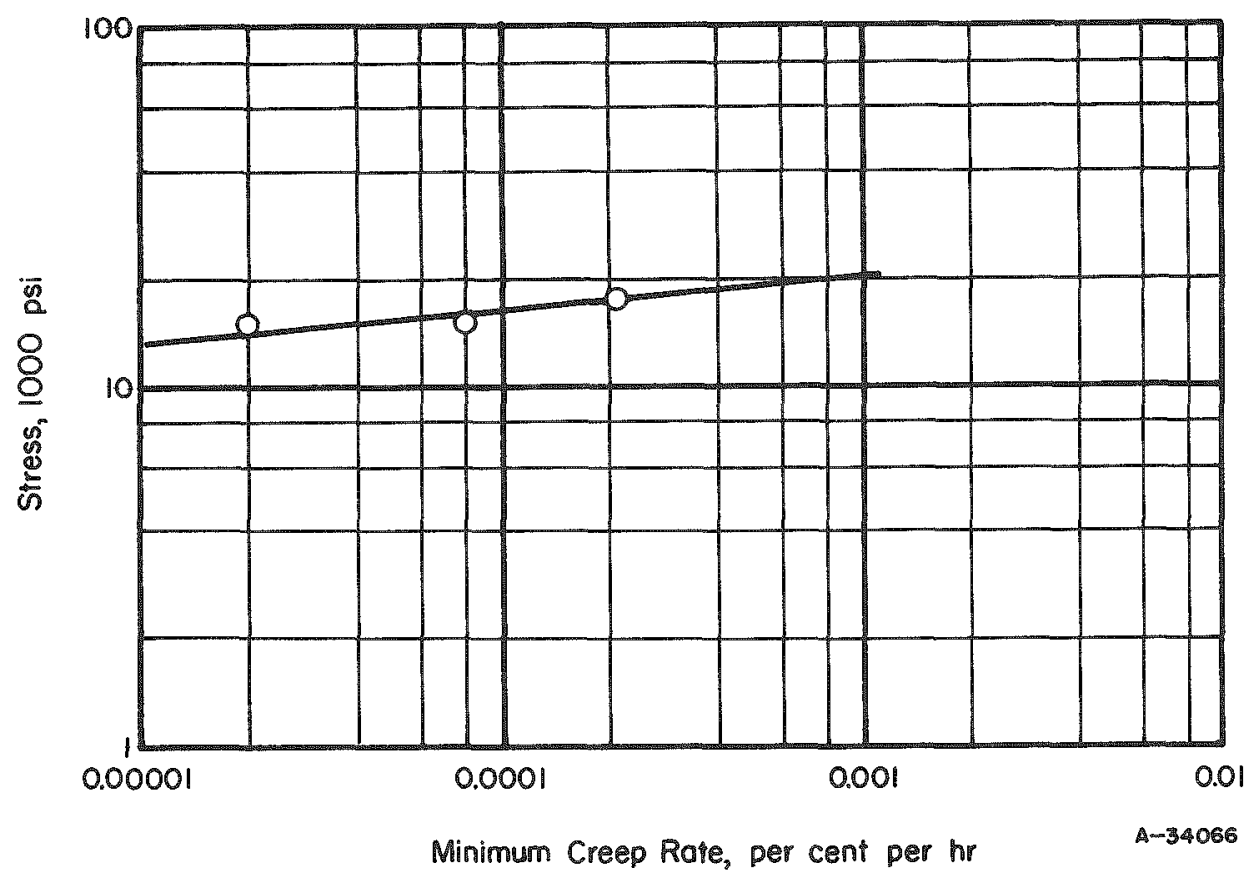

FIGURE 18. STRESS VERSUS MINIMUM CREEP RATE FOR ANNEALED ARC-CAST TANTALUM SHEET TESTED AT 1200 F IN HELIUM

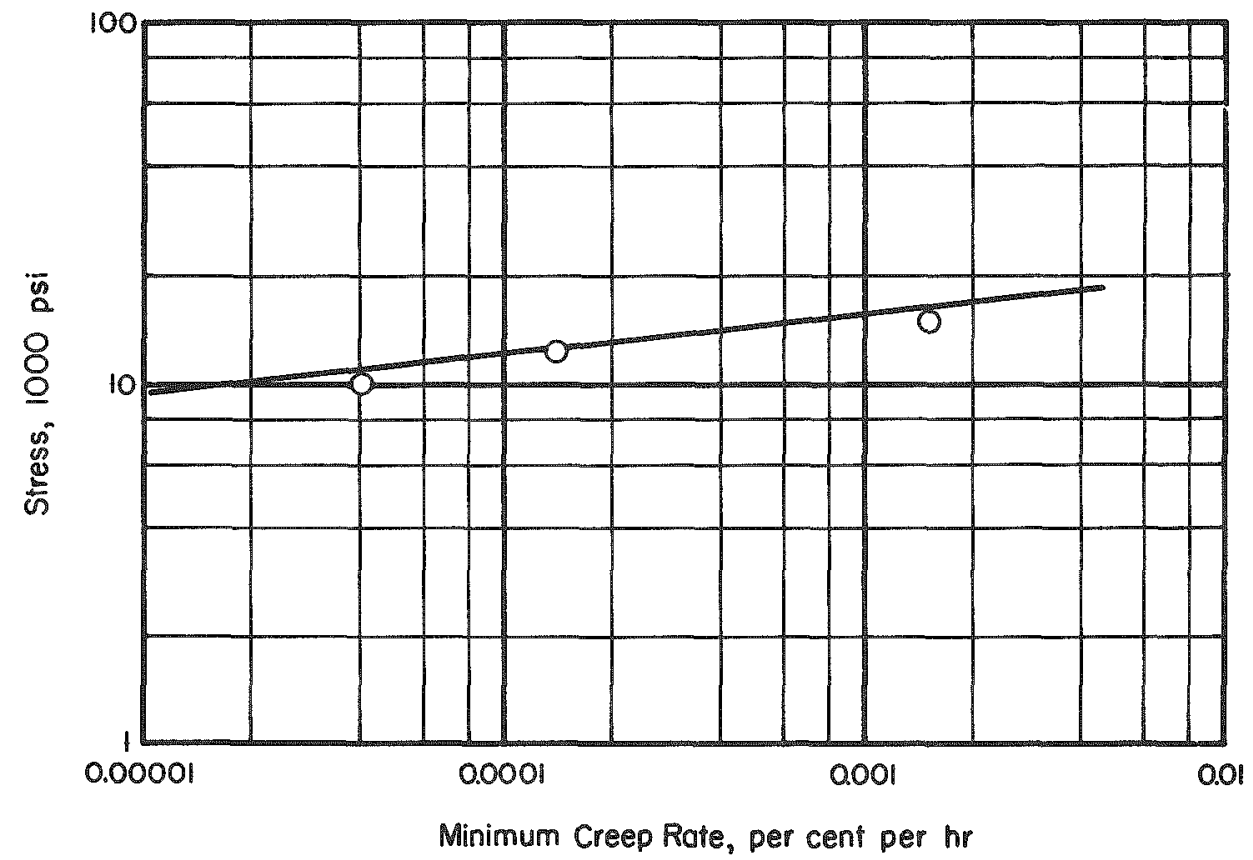

FIGURE 19. STRESS VERSUS MINIMUM CREEP RATE FOR ANNEALED SINTERED TANTALUM SHEET EXPOSED TO SODIUM FOR 33 DAYS AT $1200 \mathrm{~F}$ AND TESTED AT $1200 \mathrm{~F}$ IN HELIUM 
It was in this series of tests that zirconium linexs (10 mils thick) were placed inside the inert-atmosphere creep furnaces for the purpose of gettering gaseous contaminants. The data indicate that the zirconium liner did not eliminate the problem of contamination of the specimens by the furnace atmosphere. As in previous tests, the specimens were found to undergo a slight increase in hardness, while the levels of interstitials, particularly oxygen, were substantially higher than before creep testing. The apparent increase in impurity level without an appreciable increase in hardness led to the belief that the creep behavior was not dependent upon interstitial contaminations during creep testing.

Sodium-Exposed Annealed Sintered Tantalum

Low-oxygen-content tantalum can be obtained without changing the grain size by exposing it to hot purified sodium. In order to obtain sodium-degassed specimens for testing, material prepared from rolled sintered tantalum was annealed 8 min at about 2600 to $2675 F$ and then exposed to flowing sodium, continuousiy purified by gettering with heated zirconium, at $1200 \mathrm{~F}$ for 33 days. The surface of the specimens was examined after the sodium exposure for evidence of corrosion. Hardness measurements and chemical analyses were obtained before and after the sodium exposure and are given in Table 6. These data show that exposure to the sodium reduced the oxygen content from about $270 \mathrm{ppm}$ to about $30 \mathrm{ppm}$.

The results of the creep tests on this low-oxygen-content annealed sintered material are given in Table 7 and Figure 19. It is important to note that the strength as given in Table 7 appears to be about the same as that of the previously discussed highgas-content annealed sintered tantalum, namely, a creep rate of about 0.00005 per cent per hr at a stress of 10,000 psi. It had been expected that the large reduction in oxygen content would result in a greater loss of strength, but apparently the loss of oxygen does not appreciably reduce the creep strength of tantalum when hydrogen and nitrogen are present in the amounts shown in Table 6 and when the original grain size is maintained.

\section{As-Rolled and Welded Arc-Cast Tantalum}

An objective of this investigation was to determine the strength of tantalum weldments at $1200 \mathrm{~F}$. In order to obtain tantalum weldments for testing, a bead-on-plate weld was made on a 30 -mil-thick sheet of as-rolled arc-cast tantalum by Fansteel. Creep specimens were machined from the welded sheet with the weld located transversely at the center of the reduced section. In addition to these, creep specimens were also machined from the as-rolled sheet and were used as control specimens. Hardness and chemical-analysis data for this Fansteel arc-cast material are given in Table 1 .

The results of the creep tests at $1200 \mathrm{~F}$ on the tantalum weldments and control specimens are given in Table 8. Although greater initial deformation occurred in one of the welded specimens, the data show that the strength of the tantalum weldments was about the same as that of the as-rolled specimens. For example, at a stress of 15,000 psi the creep rates were about 0.000015 and 0.000035 per cent per hr for the weldments and the as-rolled material, respectively. It is interesting to note that the strength of the as-rolled specimens is the same as that of the annealed arc-cast tantalum material discussed earlier. 
TABLE 6. HARDNESS AND ANALYTICAL DATA ON ANNEALED SINTERED TANTALUM SPECIMENS BEFORE AND AFTER EXPOSURE TO SODIUM AT 1200 F FOR 33 DAYS

\begin{tabular}{lcc}
\hline \hline & $\frac{\text { After Exposure }}{\text { Before Exposure }}$ & 130 \\
Average Hardness (5-Kg Load), VHN & 170 & $15-43$ \\
Oxygen, ppm & $260-285$ & $5-6$ \\
Hydrogen, ppm & 1.3 & $130-270$ \\
Nitrogen, ppm & $10-140$ & 10 \\
Carbon, ppm & 10 & 130 \\
\hline
\end{tabular}

TABLE 7. CREEP AT $1200 \mathrm{~F}$ OF ANNEALED SINTERED TANTALUM AFTER EXPOSURE TO SODIUM AT $1200 \mathrm{~F}$ FOR 33 DAYS

\begin{tabular}{|c|c|c|c|c|c|c|c|c|c|c|c|}
\hline \multirow[b]{2}{*}{ Specimen } & \multirow{2}{*}{$\begin{array}{c}\text { Stress }_{\mathrm{s}} \\
\text { psi }\end{array}$} & \multirow{2}{*}{$\begin{array}{l}\text { Time in } \\
\text { Progress } \\
\text { hr }\end{array}$} & \multicolumn{6}{|c|}{$\begin{array}{l}\text { Time to Reach Indicated } \\
\text { Per Cent Deformation, } \mathrm{hr}\end{array}$} & \multirow{2}{*}{$\begin{array}{c}\text { Initial } \\
\text { Deformation, } \\
\text { per cent }\end{array}$} & \multirow{2}{*}{$\begin{array}{c}\text { Total } \\
\text { Deformation, } \\
\text { per cent }\end{array}$} & \multirow{2}{*}{$\begin{array}{c}\text { Minimum } \\
\text { Creep Rate, } \\
\text { per cent per hr }\end{array}$} \\
\hline & & & 0.1 & 0.2 & 0.5 & 1.0 & 2 & 5 & & & \\
\hline $5-3$ & 15,000 & 1704.4 & $<1$ & 2 & 7.5 & 16 & 130 & 1450 & 0.084 & 0.545 & 0.0015 \\
\hline $5-6$ & 12,500 & 1466.3 & 20 & 40 & 1015 & -- & -- & $-\infty$ & (a) & 0.555 & 0.00014 \\
\hline $5-2$ & 10,000 & 1562.9 & 400 & 850 & -- & $-\infty$ & -- & - & 0.027 & 0.26 & 0.00004 \\
\hline
\end{tabular}

(a) Specimen was bent and gave a negative value for deformation. 
TABLE 8. CREEP DATA FOR WELDED AND UNWELDED AS-ROLLED ARC-CAST TANTALUM AT $1200 \mathrm{~F}$

\begin{tabular}{|c|c|c|c|c|c|c|c|c|}
\hline Specimen & $\begin{array}{l}\text { Stress, } \\
\text { psi }\end{array}$ & $\begin{array}{c}\text { Time in } \\
\text { Progress. } \\
\mathrm{hr}\end{array}$ & \multicolumn{3}{|c|}{$\begin{array}{l}\text { Time to Reach Indicated } \\
\text { Per Cent Deformation。 hr }\end{array}$} & $\begin{array}{c}\text { Initial } \\
\text { Deformation, } \\
\text { per cent }\end{array}$ & $\begin{array}{c}\text { Total } \\
\text { Deformation, } \\
\text { per cent }\end{array}$ & $\begin{array}{c}\text { Minimum } \\
\text { Creep Rate, } \\
\text { per cent per hr }\end{array}$ \\
\hline & & & ed Sp & As & $c-$ Cas & m Sheet & & \\
\hline$W-1$ & 15,000 & 1724.2 & 0.1 & 10 & -- & 0.100 & 0.391 & 0.000015 \\
\hline \multirow[t]{2}{*}{$W-2$} & 17,500 & 1099.4 & 0.1 & 5 & 175 & 0.100 & 0.74 & 0.00022 \\
\hline & \multicolumn{6}{|c|}{ As-Rolled Arc-Cast Tantalum Sheet } & & \\
\hline$A=1$ & 15,000 & 1656.2 & 11 & 825 & $=-$ & 0.100 & 0.238 & 0.00004 \\
\hline$A-2$ & 15,000 & 1031.8 & 16 & 600 & $=-$ & 0.058 & 0.185 & 0.00003 \\
\hline
\end{tabular}




\section{DISCUSSION}

Creep-Test Results

It is interesting to make a few comparisons among the results of the creep tests at $1200 \mathrm{~F}$ in helium on the different types of tantalum investigated. The tabulation in Table 9 summarizes the data to show the stress required to produce 0.5 per cent deformation in 100 and $1000 \mathrm{hr}$ and an extrapolation to $10,000 \mathrm{hr}$. The highest strength materials were the arc-cast tantalum in the as-rolled, as-annealed, or welded condition and the thermally degassed fine-grained sintered tantalum.

The effect of gaseous impurities, namely, hydrogen, nitrogen, and oxygen on the high-temperature strength of tantalum was not clearly discernible. However, the results of this investigation did indicate that there may be other factors which affect the high-temperature strength of tantalum substantially. These are (1) method of manufacture, (2) grain size, and (3) treatments performed on the material. An illustration of the first factor can be seen in Table 9. The analyses of annealed sintered and annealed arc-cast tantalum are shown to be very similar, but the strength of the annealed arc-cast material was considerably greater. The effect of grain size can be seen by a comparison of the results for large- and small-grained thermally degassed material. The thermally degassed fine-grained tantalum (produced by the process of thermal degassing, cold rolling, and vacuum annealing), although it was very low in impurities, possessed a slightly higher strength than the annealed arc-cast tantalum, which contained about ten times as much total gaseous impurities. On the other hand, the data for annealed sintered tantalum, and for the same material exposed to purified sodium, show that the chemical analyses for these two materials were essentially the same, except for the oxygen content, which was lower for the sodium-exposed material. However, the strengths of both the low-and high-oxygen-content material were about equal.

Effect of Oxygen and Nitrogen on the Hardness of Tantalum

One of the room-temperature properties of tantalum used in an attempt to obtain an indication of the oxygen content in the metal was hardness. However, this property was shown to be unreliable, because the hardness of tantalum is related not only to the oxygen content, but also to the hydrogen and nitrogen content. A study of the effect of these three gases on the hardness of tantalum was conducted at LASL and indicated that the effects of oxygen and nitrogen were additive in increasing the hardness; hydrogen was also found to increase the hardness, but to a lesser degree.(2)

During the course of this investigation on the high-temperature mechanical properties of tantalum, a very limited amount of data for hardness versus total oxygen and nitrogen content were accumulated and an attempt has been made to correlate the values. Figure 20 is a plot of these data for sintered tantalum having a hydrogen content of from 0.2 to $1.4 \mathrm{ppm}$. The curve indicates that a Vickers hardness of about 70 and 160 may be expected with a total oxygen and nitrogen content of about 30 and 400 ppm, respectively. 
TABLE 9. IARONESSES, ANALYSES, AND CRETP STRENGTHS OF VARIOUS TYPES OF TANTALUM TESTED AT 1200 F IN A IIELIUM ATMOSPIERE

\begin{tabular}{|c|c|c|c|c|c|c|c|c|}
\hline \multirow[b]{2}{*}{ Tantalum $(a)$} & \multirow{2}{*}{$\begin{array}{l}\text { Tardness, } \\
\text { VHN (5 } \mathrm{Kg})\end{array}$} & \multicolumn{4}{|c|}{ Chemical Analysis, ppm } & \multicolumn{3}{|c|}{$\begin{array}{c}\text { Approximate Stress Required to Produce } \\
0.5 \text { Per Cent Deformation in } \\
\text { Time Indicated, psi } \\
\end{array}$} \\
\hline & & Carbon & IIydrogen & Nitrogen & Oxygen & $100 \mathrm{IIr}$ & $1000 \mathrm{Hr}$ & $10,000 \mathrm{Hr}$ \\
\hline Annealed, sintered & $161-183$ & 10 & $1.3-1.6$ & $130-140$ & $240 \times 300$ & 13,000 & 11,500 & 10,000 \\
\hline Annealed, arc cast & $176-205$ & $<10$ & $<0.3$ & 150 & 214 & 17.000 & 15,000 & $\infty$ \\
\hline $\begin{array}{l}\text { Thermally degassed, large } \\
\text { grained, smiered }\end{array}$ & $89 \cdot 115$ & $<10$ & 0.2 & 50 & 2 & 6,500 & 5,500 & 4,800 \\
\hline $\begin{array}{l}\text { Annealed, sintered tantalum } \\
\text { after exposure to sodium }\end{array}$ & 130 & 10 & $5-6$ & $130 \times 270$ & $15-36$ & - & 12,500 & $-\infty$ \\
\hline $\begin{array}{l}\text { Thermally degassed, finem } \\
\text { grained, sintered }\end{array}$ & $71-79$ & $20-30$ & 0.7 & 20 & $10-16$ & $\infty$ & 16,000 & $12,000-14,000$ \\
\hline
\end{tabular}

(a) Annealing and degassing data are given in the rext. 


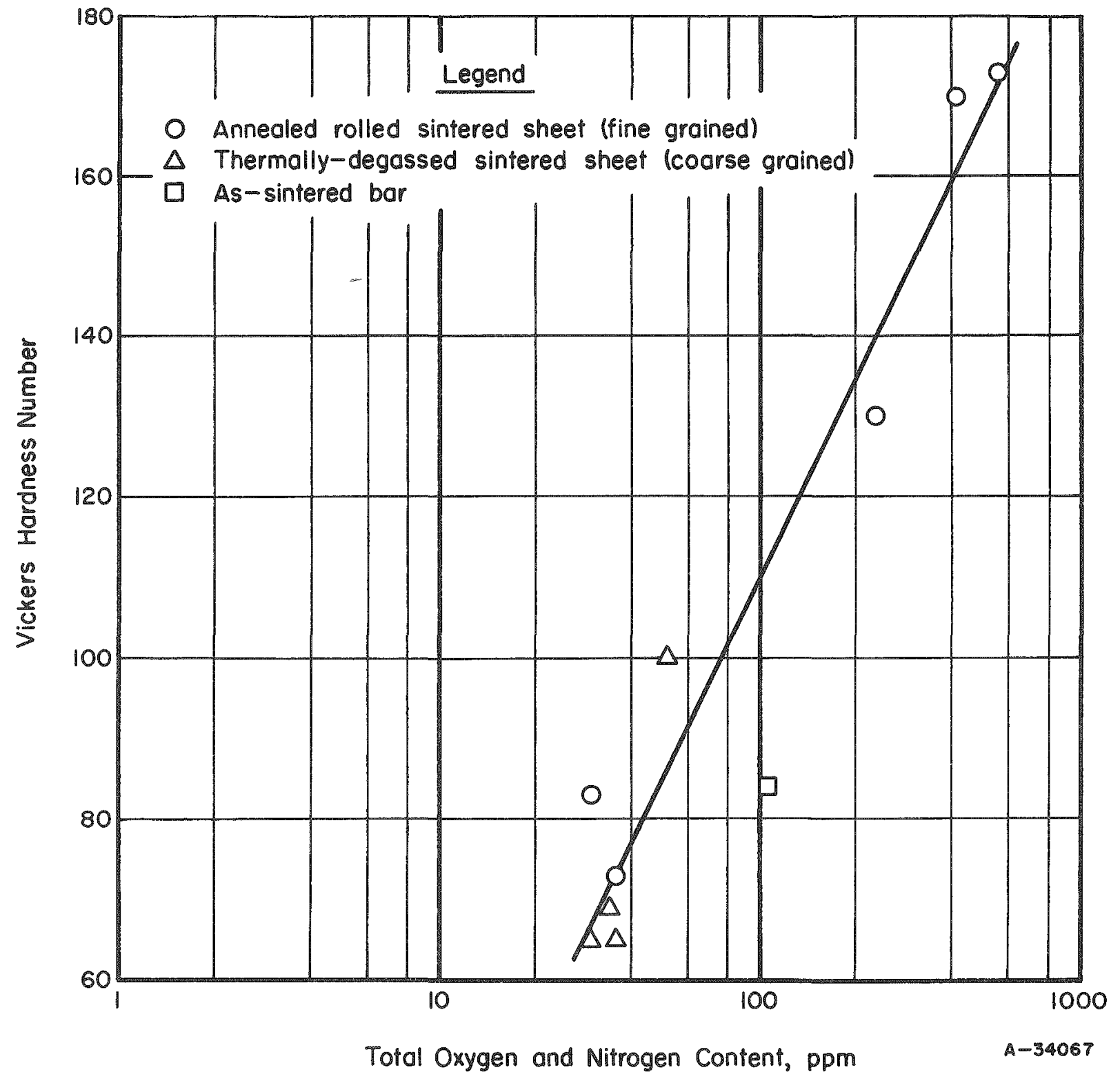

FIGURE 20. EFFECT OF OXYGEN AND NITROGEN ON THE HARDNESS OF TANTALUM 


\section{REFERENCES}

(1) Malter, L., and Langmuir, D. B., "Resistance, Emissivities, and Melting Point of Tantalum", Phys. Rev., 55, 743-74.7 (1939).

(2) Perkins, R., "Tantalum Annealing and Degassing and Hardness Effects of Dissolved Gases", LA-2136 (September 30, 1957).

DCD:MEL:CJS:JGD/ims 